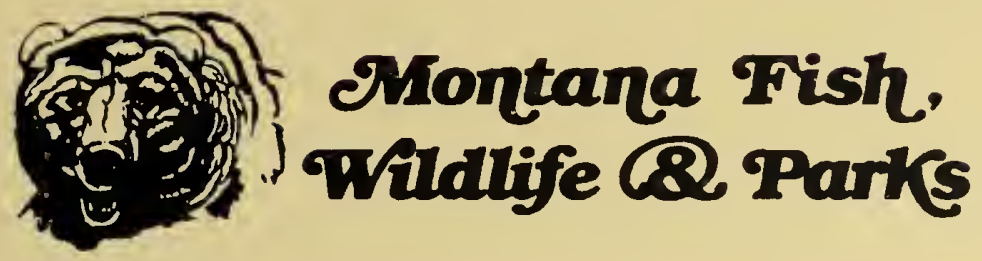

\title{
INVESTIGATION OF TRACE METALS IN AQUATIC INSECTS AND BED SEDIMENTS OF THE LOWER CLARK FORK RIVER, 1996-1997
}

by

Don Skaar and Kurt Hill Montana Fish, Wildlife and Parks 1420 East $6^{\text {th }}$ Avenue Helena, MT 59620

for the

U.S. Environmental Protection Agency and

Montana Department of Environmental Quality

March 1999 


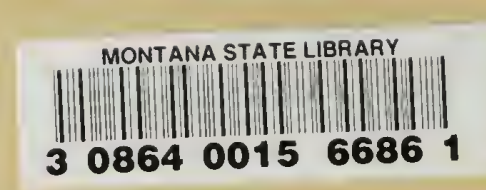


Investigation of trace metals in aquatic insects and bed sediments of the lower Clark Fork River, 1996-1997.

\author{
by \\ Don Skaar and Kurt Hill \\ Montana Fish, Wildlife and Parks \\ 1420 East 6th Avenue \\ Helena, Montana 59620 \\ for the

\section{U.S. Environmental Protection Agency \\ and \\ Montana Department of Environmental Quality}

March 1999 



\section{Table of Contents}

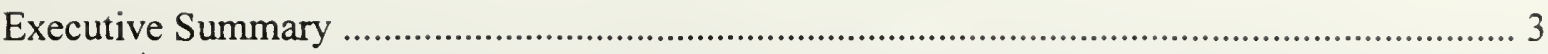

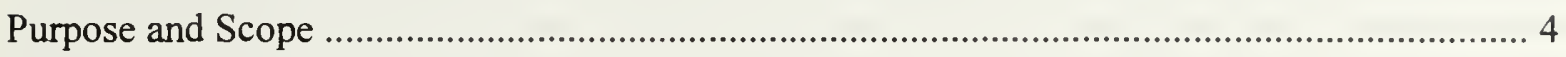

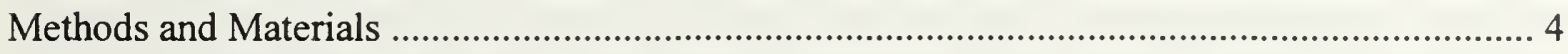

Sample Design and Collection .......................................................................................... 4

Sample Analysis and Treatment of Data ........................................................................... 5

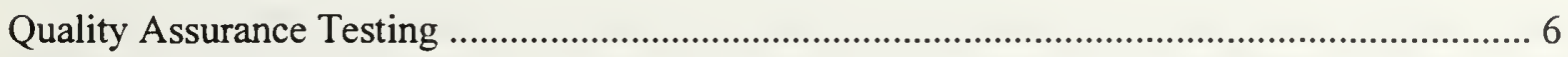

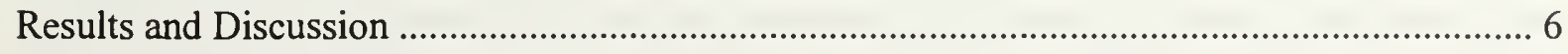

Metals in fine-grained sediments ...........................................................................................6

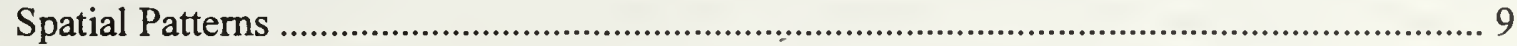

Temporal Patterns .......................................................................................................... 9

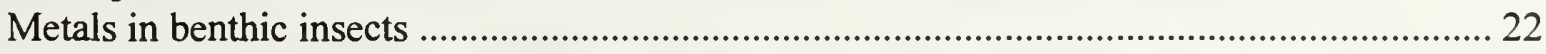

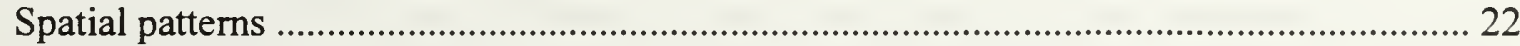

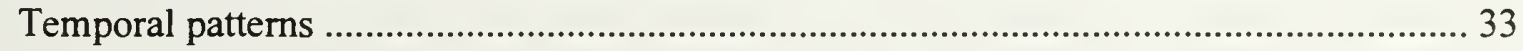

Community Composition of benthic invertebrates ...................................................................46

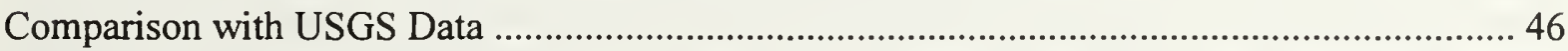

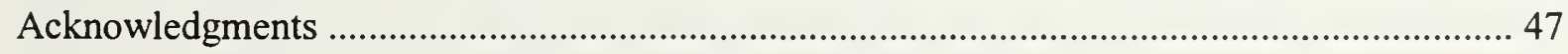

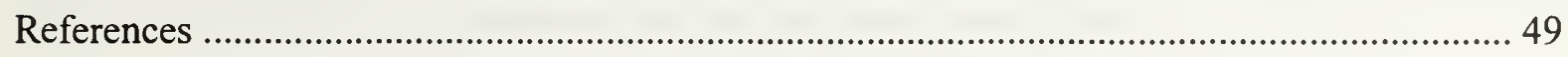





\section{Executive Summary}

Fine-grained bed sediments and benthic macroinvertebrates were collected from three sites on the Clark Fork River (East Missoula, Missoula, Alberton) on six occasions (July, September and November 1996; March and August 1997). Sediment and insect samples were analyzed for trace elements believed to be contaminants at this site. Insect species for which analyses were conducted included Hydropsyche cockerelli, H. occidentalis, Pteronarcys californica, Claassenia sabulosa, and Arctopsyche grandis.

The mean concentrations of copper and zinc in fine-grained sediments were highest at the Missoula site. The concentrations of both metals at Missoula were not significantly different from concentrations at East Missoula, while both sites were significantly different (and greater) than concentrations at Alberton. The East Missoula site showed no temporal trends for either metal, while at both the Missoula and Alberton sites, concentrations of both copper and zinc were significantly different (and lower) in July 1996 than those measured in August 1997.

The East Missoula site had significantly greater mean copper and zinc concentrations than the Missoula and Alberton sites for all insect species, with the exception of Claassenia, which was similar at all sites. In no case was the mean copper or zinc concentration at Missoula significantly different than Alberton. Copper concentrations in Hydropsyche cockerelli were higher in similarlyaged animals in August 1997 than in July 1996 at East Missoula and Alberton, but slightly lower at Missoula. Copper concentrations in Arctopsyche were higher in similarly-aged animals in August 1997 than in July 1996 for both East Missoula and Missoula; this was opposite the effect seen at Alberton. For Pteronarcys, copper concentrations in first- and second-year animals increased from March to August 1997, a time period spanning the spring runoff flows.

The seasonal pattern of benthic invertebrate abundance was determined for the Missoula site and results showed this pattern to be similar to that expected in temperate-region streams. Total number of organisms averaged 257.0 per sample in July 1996, rose to 423.3 in September and reached a peak of 809.7 in November. Numbers dropped substantially in January (176.7) before rising to 399.7 in August. The precipitous drop between November and January may have been due to the severe ice conditions and scour occurring at the site during this time. The seasonal pattern of abundance of individual insect taxa was also similar to what would be expected. 
Digitized by the Internet Archive in 2013

http://archive.org/details/investigationoft00skaa 


\section{Purpose and Scope}

Large quantities of ice formed on the upper Clark Fork and Blackfoot Rivers in the winter of 1995-1996. A thaw occurred in early February 1996 and ice began to break up and move down the Clark Fork River. Montana Power Company personnel at the Milltown Dam quickly removed the flashboards on the spillway in order to prevent damage to the superstructure of the dam. This lowered the water level, causing significant quantities of sediment to be washed from the reservoir. In addition, ice scour along the bed and banks of the Clark Fork River immediately above the reservoir contributed to the sediment load. Trace metals in the river water below the dam were measured after this event and found to be quite high, particularly in the total recoverable fraction. On February 9, the U.S. Geological Survey (USGS) measured copper in the water at concentrations of $400 \mathrm{ug} / \mathrm{L}$ (total recoverable) and $11 \mathrm{ug} / \mathrm{L}$ (dissolved)(USEPA 1998). Montana Fish Wildlife and Parks (MFWP) was concerned about the effects of these metals on the aquatic ecosystem of the river below Milltown, and initiated a one year study. The first sampling session in July 1996 was intended to determine if the metals mobilized by this ice event had a lingering effect on the insects and sediment of the river. Subsequent sampling between July 1996 and August 1997 was intended to establish reference levels of contamination from which the effects of future hydrological events could be evaluated.

\section{Methods and Materials}

Sample Design and Collection. The sampling design was based upon the objective of quantifying temporal and spatial trends in trace metal concentrations in biota and sediments of the Clark Fork River below Milltown Dam. Three sites were chosen for this purpose: 1) the East Missoula site near the Sha-Ron Fishing Access Site in East Missoula (T13N, R19W, sec13). Exact location of sample collections varied, but all were within the area from the boat ramp upstream about 600 feet to the pipeline crossing. This site is the same location as the "Clark Fork above Missoula" site of the USGS (Hornberger et al. 1997) and "Station 15.5" of the Montana Department of Environmental Quality (McGuire 1997); 2) the Missoula site was near the Kelly Island Fishing Access site in Missoula (T13N, R20W,sec20). Exact location of samples varied--invertebrates were taken anywhere from the mouth of the Bitterroot River to about 1000 feet above the access site. Sediments were sampled at the access site in July 1996, but thereafter were collected upstream between the Reserve Street Bridge and the Missoula Wastewater Treatment plant; 3) the Alberton site was located downstream of the town of Alberton (T15N, R23W, sec32). This site is the same as the "Clark Fork River below Missoula" station of the USGS (Hornberger et al 1997). The bulk of invertebrates were collected from the same riffle area used by the USGS, but occasionally a stretch of river a mile above and below this station was used. Sediments were sampled from this station in July and September 1996, but thereafter were sampled about two miles upstream at the Natural Pier Fishing Access Site.

Bed sediments and benthic macroinvertebrates were collected for metals analysis using the methods and procedures of Dodge et al. (1997). Three bed sediment samples were collected from 

each site. Sediments were collected from the surface of depositional areas along the river margin, usually in the slow areas behind rocks. Acid-washed polypropylene scoops were used to collect the sediment. Sediments that appeared to be in a reduced state (darker color) were not sampled. Sediments were passed through a 63 um filter, using river water as a carrier, and stored in $500 \mathrm{~mL}$ plastic bottles.

Benthic macroinvertebrates were usually collected on the same day as the sediments. Five benthic insect species were targeted for metals analysis: three caddisflies (Hydropsyche cockerelli, Hydropsyche occidentalis, Arctopsyche grandis) and two stoneflies (Pteronarcys californica, and Claassenia sabulosa). These taxa were selectively removed from kick-net samples and placed in acid-rinsed plastic containers filled with river water. The taxa were held together in the containers; separate containers were not provided for individual species. The containers were placed on ice for 6-10 hours to allow the insects to depurate the contents of their digestive tracts. After this time, the water was drained and the insects immediately frozen. To determine community composition, benthic macroinvertebrates were collected with a modified Hess sampler ( 0.1 square meter diameter, $1 \mathrm{~mm}$ mesh), using methods described by McGuire (1997). Three replicate samples were collected from each site, selecting the most heterogenous habitat in riffles. Samples were placed in 1-quart Mason jars and preserved with ethanol. Samples were collected at all sites on five occasions between July 1996 and August 1997. The only exception to this was January 1997, when ice conditions precluded sampling at all sites but Missoula.

Sample Analysis and Treatment of Data. For metals analysis, insects samples were thawed and individuals were identified and sorted by species and size groups. There were usually 50-100 individuals per size group for the caddisfly species, while 10-20 individuals was more typical for the stoneflies. For the largest size groups of stoneflies, there were occasions where as few as five individuals were used. For the largest Claassenia (greater than $25 \mathrm{~mm}$ in length) there was probably no uncertainty with regard to correct identification, but with smaller animals there was probably occasional misidentification of a few individuals which may have been any one of the following genera: Isogenoides, Skwala, Calineuria. Ten individuals from each size group were measured for total length. Each insect sample was rinsed with distilled water, transferred to acid-washed plastic centrifuge vials and placed in an oven at $60^{\circ} \mathrm{C}$ until dry. These samples were then ground with a mortar and pestle and prepared for metals analysis by microwave-digestion for approximately 6 minutes in a solution of $4 \mathrm{~mL}$ nitric acid and $1 \mathrm{~mL}$ hydrochloric acid. The digestate was then brought to a $50 \mathrm{~mL}$ volume with distilled water. Samples were then analyzed by graphite furnace AAS (Atomic Absorption Spectroscopy) or ICP (Inductively Coupled Plasma) analysis. The procedure for metals analysis of sediments was similar to insects, except that sediments were dried in the same plastic vials in which they had been collected.

Statistical calculations and tests were performed by using SPSS software (SPSS, 1993). Determinations of statistical significance were based on $\mathrm{P}<0.05$ levels. 



\section{Quality Assurance Testing}

Procedural blanks for bed sediment and insect samples contained the same reagents (nitric and hydrochloric acid, distilled water) that were used for sample preparation. Zinc was the only element for which contamination was detected (Table 1). One of these contaminated samples had a concentration of $0.006 \mathrm{ug} / \mathrm{mL}$, which is very near to the detection limit $(0.005 \mathrm{ug} / \mathrm{mL})$, while the other sample was much higher $(0.032 \mathrm{ug} / \mathrm{mL})$. This highly contaminated blank actually contained $0.32 \mathrm{ug}$ zinc $(0.032 \mathrm{ug} / \mathrm{mL} \mathrm{X} 10 \mathrm{~mL})$, which is about $4 \%$ of the amount of zinc in the insect samples in this study ( $80 \mathrm{ug} / \mathrm{g}$ zinc X $0.10 \mathrm{~g}$ dry weight $=8 \mathrm{ug}$ zinc) or $1 \%$ of the amount of zinc in the sediment samples $(120 \mathrm{ug} / \mathrm{g}$ zinc $X 0.25 \mathrm{~g}$ dry weight $=30 \mathrm{ug}$ zinc). These errors are considered minor and no adjustment was made to any of the insect or bed-sediment values.

Standard reference materials used in this study were bovine liver (as a surrogate for insect tissue) and sediment. Mean recovery efficiency for bovine liver was within $90 \%$ of the certified concentration for copper and cadmium, but was low for zinc (68\%) and high for lead (198\%) and arsenic (206\%)(Table 2). Recovery for sediments was much better; mean recovery efficiency ranged from $97 \%$ for arsenic to $105 \%$ for zinc. The $95 \%$ confidence intervals for recovery efficiency were always greater than the error considered acceptable. The certified acceptance limits were about 90 and $110 \%$ of the mean value for arsenic, cadmium, lead and zinc, and 60 and $140 \%$ for copper. In comparison, the confidence levels that were achieved were about 80 and $120 \%$ of the mean value for arsenic, cadmium, lead and zinc, and 55 and $145 \%$ for copper.

\section{Results and Discussion}

Metals in fine-grained sediments. An understanding of the trends in sediment metals must include an examination of the hydrologic events that transported sediments to the sites, and the extent to which the sampled sediments were reflective of those events. The discharges occurring at our three sites are fairly well portrayed by measurements taken at the USGS gage stations above Missoula (near East Missoula) and below Missoula (below the confluence of the Bitterroot River). The discharges measured near East Missoula should be very similar to those occurring at our East Missoula and Missoula sites, while the discharges from the station below Missoula are somewhat less than those occurring at our Alberton site. At both stations, the peak flows from the February 1996 ice-out occurred on the 10th, when flows averaged 12,900 cfs above Missoula and 20,300 cfs below Missoula. Over 31,000 tons of sediment were discharged from Milltown Dam during the four peak days of the February event (USEPA 1998). These sediments were probably transported farther downstream as a result of the higher flows during spring runoff in 1996. These flows peaked at $18,300 \mathrm{cfs}$ on June 10 above Missoula and at 37,400 cfs on May 19 below Missoula. After the spring runoff in 1996, the hydrograph followed a typical pattern of flows dropping through the fall and winter. High flows were not seen on the river again until spring 1997. The 1997 flows were much higher than in 1996 and peaked on May 18 at both stations when discharge got to 26,400 cfs above Missoula and 54,100 cfs below Missoula. 



\begin{tabular}{|c|c|c|c|c|c|c|}
\hline \multirow{2}{*}{ Sample Period } & \multirow{2}{*}{$\begin{array}{l}\text { Dilution } \\
\text { Ratio } \\
\end{array}$} & \multicolumn{5}{|c|}{ Metal concentration (ug/mL) } \\
\hline & & Arsenic & Cadmium & Copper & Lead & Zinc \\
\hline July 1996 & $1: 9$ & $<0.001$ & $<0.001$ & $<0.005$ & $<0.001$ & $<0.005$ \\
\hline July 1996 & $1: 9$ & $<0.001$ & $<0.001$ & $<0.005$ & $<0.05$ & $<0.005$ \\
\hline July 1996 & $1: 9$ & $<0.001$ & $<0.001$ & $<0.005$ & $<0.001$ & $<0.005$ \\
\hline September 1996 & 1:9 & $<0.001$ & $<0.001$ & $<0.005$ & $<0.001$ & $<0.005$ \\
\hline September 1996 & $1: 9$ & $<0.001$ & $<0.001$ & $<0.005$ & $<0.05$ & $<0.005$ \\
\hline September 1996 & $1: 9$ & $<0.001$ & $<0.001$ & $<0.005$ & $<0.05$ & $<0.005$ \\
\hline November 1996 & $1: 9$ & $<0.001$ & $<0.001$ & $<0.005$ & $<0.05$ & $<0.005$ \\
\hline November 1996 & $1: 9$ & $<0.001$ & $<0.001$ & $<0.005$ & $<0.05$ & 0.032 \\
\hline March 1997 & $1: 9$ & $<0.001$ & $<0.002$ & $<0.005$ & $<0.001$ & 0.006 \\
\hline March 1997 & $1: 9$ & $<0.001$ & $<0.001$ & $<0.005$ & $<0.05$ & $<0.005$ \\
\hline August 1997 & $1: 9$ & $<0.001$ & $<0.001$ & $<0.005$ & $<0.05$ & $<0.005$ \\
\hline August 1997 & $1: 9$ & $<0.001$ & $<0.001$ & $<0.005$ & $<0.05$ & $<0.005$ \\
\hline
\end{tabular}



Table 2. Recovery efficiency for metal analysis of standard reference materials (SRM) for insects and sediment.

\begin{tabular}{||l|l|l|l|l|}
\hline Metal & $\begin{array}{l}\text { Number of } \\
\text { measurements }\end{array}$ & $\begin{array}{l}\text { Certified } \\
\text { concentration } \\
\text { (ug/g) }\end{array}$ & $\begin{array}{l}\text { SRM recovery (ug/g) } \\
\text { Mean } 95 \% \mathrm{CI}\end{array}$ & $\begin{array}{l}\text { Acceptance } \\
\text { limits for SRM } \\
\text { (ug/g) }\end{array}$ \\
\hline \hline
\end{tabular}

\begin{tabular}{|c|c|c|c|c|c|}
\hline \multicolumn{6}{|c|}{ Insect (NBS \#1577, Bovine Liver) } \\
\hline Arsenic & 5 & $0.050^{*}$ & 0.103 & $0.025-0.181$ & $\ldots * *$ \\
\hline Cadmium & 5 & 0.50 & 0.47 & $0.43-0.51$ & -- \\
\hline Copper & 5 & 160 & 144 & $132.8-149.6$ & -- \\
\hline Lead & 4 & 0.13 & 0.257 & $0.217-0.297$ & -- \\
\hline Zinc & 4 & 127 & 86.7 & $74.7-98.7$ & -- \\
\hline \multicolumn{6}{|c|}{ Sediment (USGS \#5) } \\
\hline Arsenic & 6 & 216 & 210 & $166-256$ & $196-236$ \\
\hline Cadmium & 6 & 158 & 162 & $128-196$ & $142-174$ \\
\hline Copper & 4 & 58.9 & 66.6 & $34.1-97.1$ & $31.3-82.5$ \\
\hline Lead & 7 & 309 & 324 & $258-390$ & $291-327$ \\
\hline Zinc & 7 & 598 & 588 & $500-676$ & $551-645$ \\
\hline
\end{tabular}

*Uncertified concentration

**Ranges not provided with material 

All sediments for this study were sampled at discharges between 1,500 and 7,500 cfs, which correspond to water surface elevations 5-10 feet lower than those during spring runoff and 3-8 feet lower than during the 1996 ice-out (Table 3 ). Therefore, all of the sediment samples were clearly collected from within the portion of the channel that had been influenced by all of these events. The fact that spring runoff flows in 1996 and 1997 were much higher than during the ice-out event strongly suggests that the ice-out sediments were being transported through and downstream from our sites during the course of our study. However, we have no way to know when or where we may have sampled the ice-out sediments.

Spatial Patterns. The mean concentrations of most metals in the sediments (arsenic, copper, iron, manganese, nickel, lead and zinc) were highest at the Missoula site. Mean concentrations of silver and cadmium were highest at East Missoula, while concentrations of chromium were highest at Alberton (Tables 4 and 5). Concentrations of copper and zinc at Missoula averaged 270.5 and 556.4 $\mathrm{ug} / \mathrm{g}$, respectively, only slightly higher than the corresponding concentrations at East Missoula (247.8 and $531.9 \mathrm{ug} / \mathrm{g}$ ), but much higher than at Alberton (129.7 and $274.8 \mathrm{ug} / \mathrm{g}$ ). The data for these two metals were subjected to statistical analysis, and results showed that East Missoula and Missoula were not significantly different in terms of mean copper or zinc concentrations (Table 6), while both of these sites were significantly different (and greater) than concentrations at Alberton.

Temporal Patterns. There were distinct differences between the sites in terms of temporal changes in metals in the sediments. One-way ANOVA was used to test the null hypothesis that the metal concentrations on all sampling dates had equal means. At East Missoula, no significant differences were seen for any of the metals tested (Figures 1-4, Table 7). In contrast, the null hypothesis was rejected for arsenic, cadmium, copper, lead, and zinc at both the Missoula and Alberton sites. Measurements of copper and zinc at these two sites were subjected to further statistical analysis. Bonferroni t-test comparisons were done for the mean concentration of copper and zinc on each sampling date. Where significant differences were found, almost all showed an increase in concentration over time. At Missoula, all of the differences (10 of 10 tests) showed an increase over time, while at Alberton, 11 of 14 significant tests showed an increase over time (Tables 8 and 9). At both sites, copper and zinc levels measured in July and September 1996 were significantly different (and lower) than those measured in August 1997. These findings are qualified by the fact that the sampling location for sediments was changed for both sites during the study (after July 1996 at Missoula and after September 1996 at Alberton), and it is possible that there were differences in metal concentrations between the two locations. Nonetheless, the September 1996 levels of copper and zinc were still significantly lower at Missoula than the August 1997 samples; similarly the November 1996 copper and zinc levels at Alberton were significantly lower than in August 1997.

One possible explanation for the increase in copper and zinc levels over time at Missoula and Alberton, but not East Missoula, is that it was a reflection of the movement of the sediments that had washed out of Milltown Dam in February 1996. This explanation assumes the sediment from the reservoir had moved past the East Missoula site by the time this study began in July 1996 but was 



\begin{tabular}{|c|c|c|}
\hline Date & $\begin{array}{c}\text { Clark Fork } \\
\text { above Missoula }\end{array}$ & $\begin{array}{c}\text { Clark Fork } \\
\text { below Missoula } \\
\end{array}$ \\
\hline $2-10-96$ & 9.04 (max. elev.) & 7.54 (max. elev.) \\
\hline $5-19-96$ & -- & 9.20 (max. elev.) \\
\hline $5-10-96$ & 9.94 (max. elev.) & -- \\
\hline $7-29-96$ & 3.40 & -- \\
\hline $7-31-96$ & -- & 2.48 \\
\hline $9-3-96$ & 2.80 & -- \\
\hline $9-4-96$ & -- & 1.78 \\
\hline $11-6-96$ & 2.92 & -- \\
\hline $11-6-96$ & -- & 1.78 \\
\hline $3-25-96$ & 4.60 & - \\
\hline $3-26-96$ & -- & 4.00 \\
\hline $5-18-97$ & 12.59 (max. elev.) & 12.18 (max. elev.) \\
\hline $8-12-97$ & 3.45 & 2.63 \\
\hline
\end{tabular}




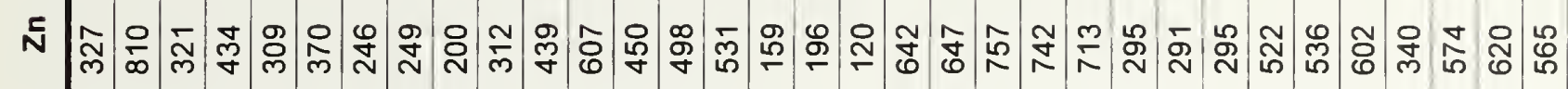

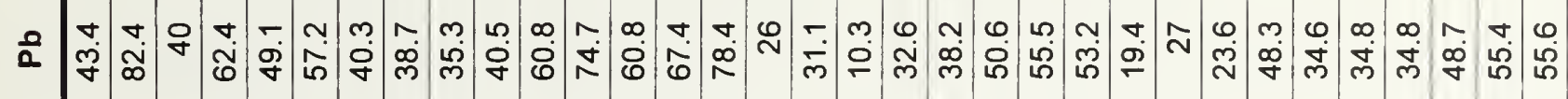

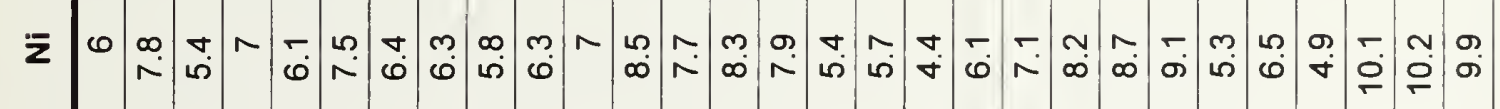

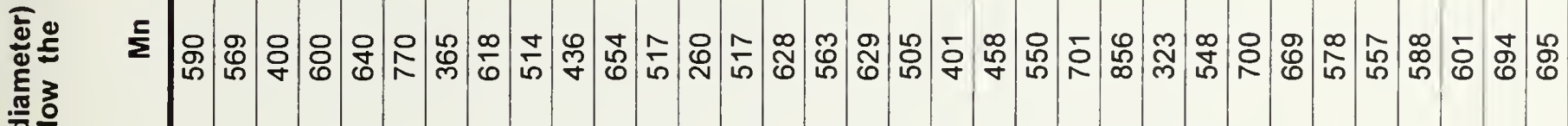

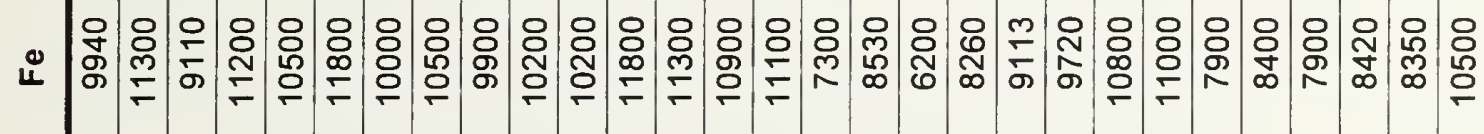

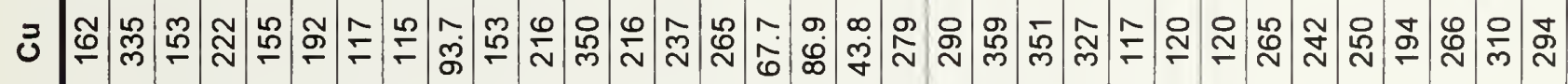

¿̀

J

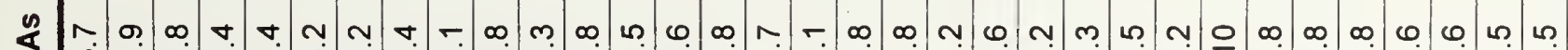

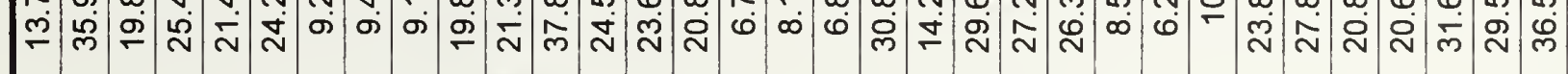

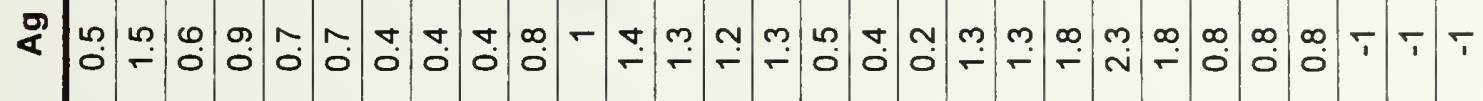

ஜ : $: \%: \%$ 产 



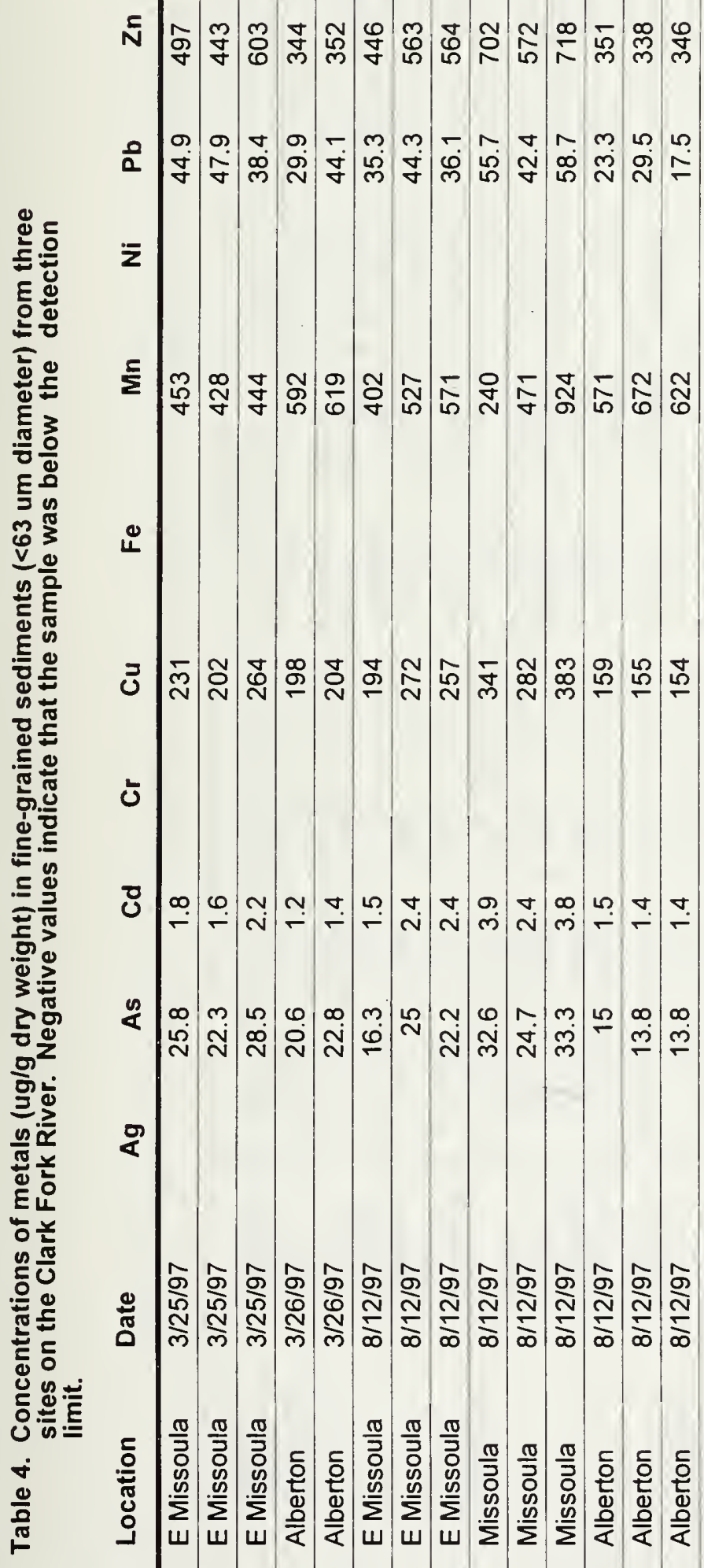





\begin{tabular}{|c|c|c|c|c|}
\hline$Z_{N}$ & 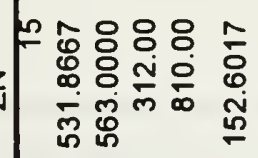 & 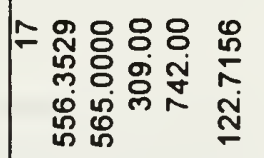 & 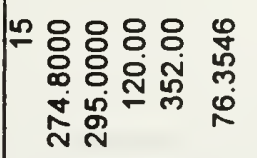 & 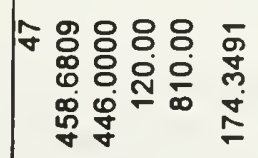 \\
\hline$\underline{Q}$ & م. & 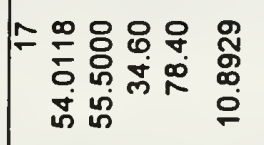 & 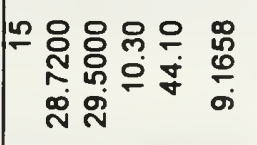 & 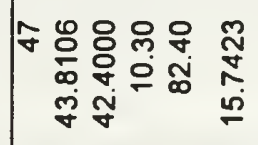 \\
\hline$\overline{\mathbf{z}}$ & 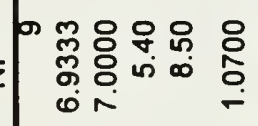 & 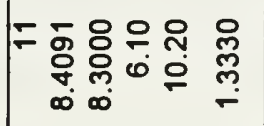 & 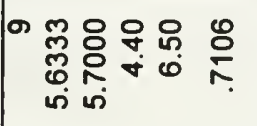 & 용ㅇㅇ요유 \\
\hline$\frac{z}{\Sigma}$ & 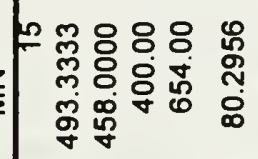 & 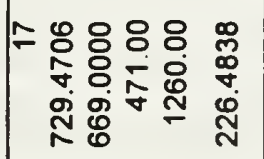 & 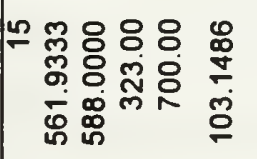 & 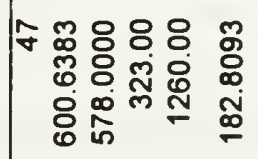 \\
\hline$\frac{1}{0}$ & 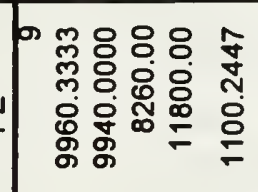 & 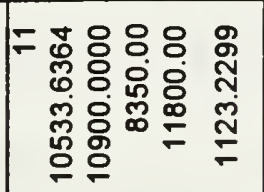 & a 立 & 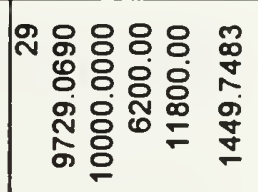 \\
\hline נִ & 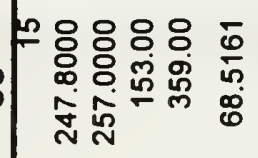 & 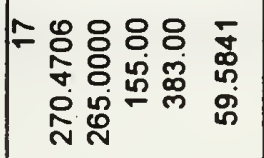 & 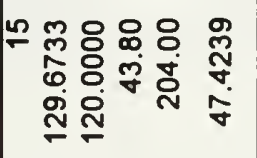 & 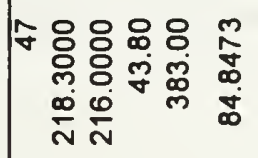 \\
\hline$\frac{\alpha}{0}$ & 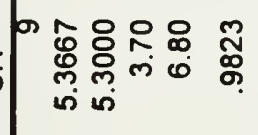 & 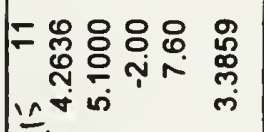 & 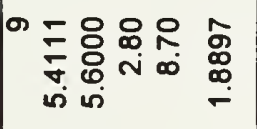 & 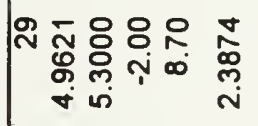 \\
\hline O & 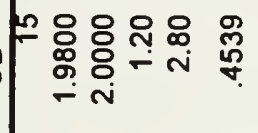 & 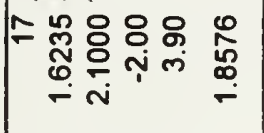 & 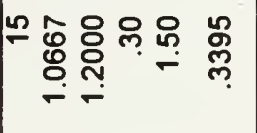 & | \\
\hline \& & 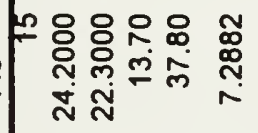 & 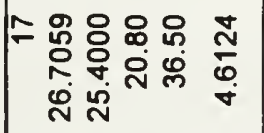 & 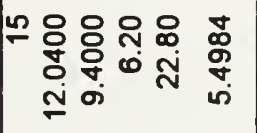 & 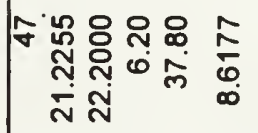 \\
\hline ర్ & ए & 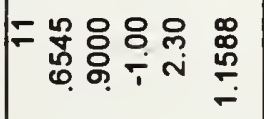 & " & 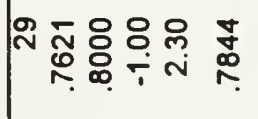 \\
\hline $\begin{array}{l}\frac{3}{5} \\
\frac{0}{50} \\
\frac{\pi}{5}\end{array}$ & 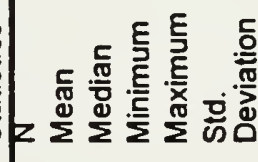 & Z & 々 & 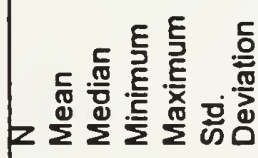 \\
\hline$\frac{w}{\omega}$ & 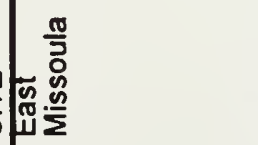 & 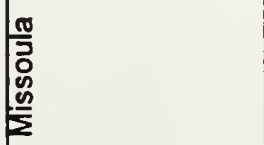 & 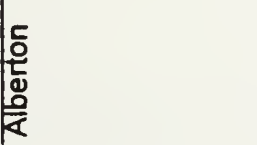 & 荙 \\
\hline
\end{tabular}


|

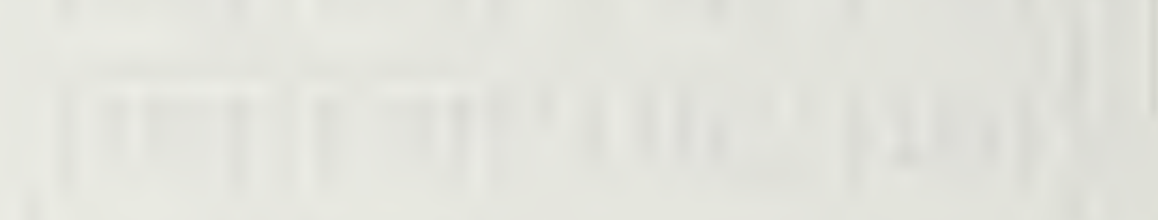

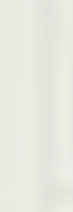

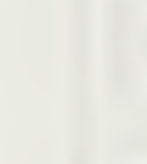

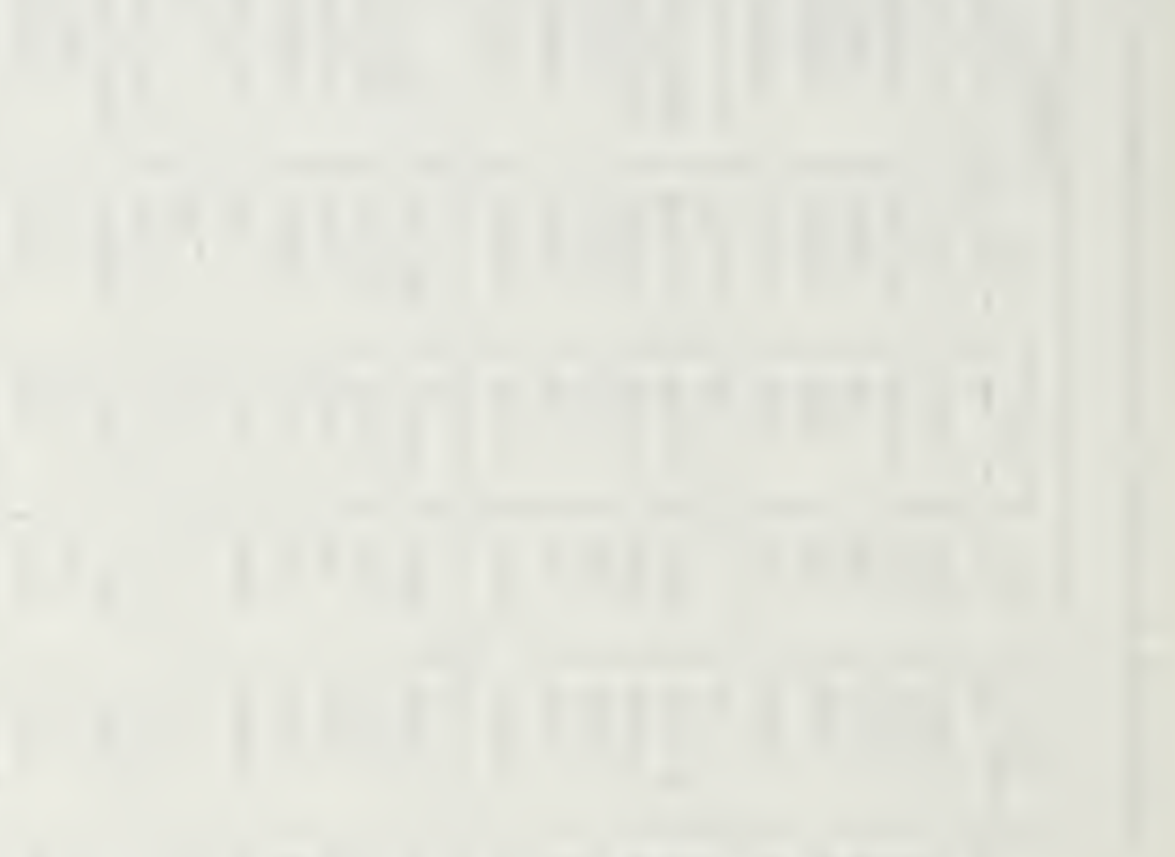

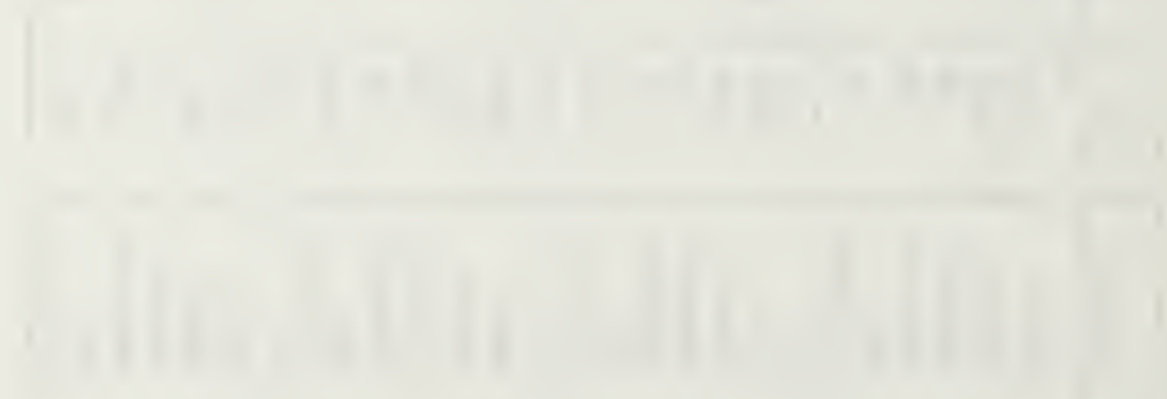

1 
Table 6. Comparisons of mean copper and zinc concentrations in fine-grained sediments at the three sites. Levels of significance $(\mathrm{P})$ are based on Bonferroni t-test comparisons.

\begin{tabular}{||l|l|l|c|c||}
\hline \hline $\begin{array}{l}\text { Dependent } \\
\text { variable }\end{array}$ & \multicolumn{2}{c|}{ Site A } & $\begin{array}{l}\text { Mean Difference } \\
\text { (A-B) }\end{array}$ & Sig. \\
\hline \hline \multirow{3}{*}{ Copper } & $\begin{array}{l}\text { East } \\
\text { Missoula }\end{array}$ & Missoula & -22.7 & .856 \\
\cline { 2 - 5 } & $\begin{array}{l}\text { East } \\
\text { Missoula }\end{array}$ & Alberton & $118.1^{*}$ & .000 \\
\cline { 2 - 5 } & Missoula & Alberton & $140.8^{*}$ & .000 \\
\hline \hline \multirow{2}{*}{ Zinc } & $\begin{array}{l}\text { East } \\
\text { Missoula }\end{array}$ & Missoula & -24.5 & 1.000 \\
\cline { 2 - 6 } & $\begin{array}{l}\text { East } \\
\text { Missoula }\end{array}$ & Alberton & $257.1^{*}$ & \\
\cline { 2 - 5 } & Missoula & Alberton & $281.6^{*}$ & .000 \\
\hline
\end{tabular}

*The mean difference is significant at the $\mathrm{P}=0.05$ level. 



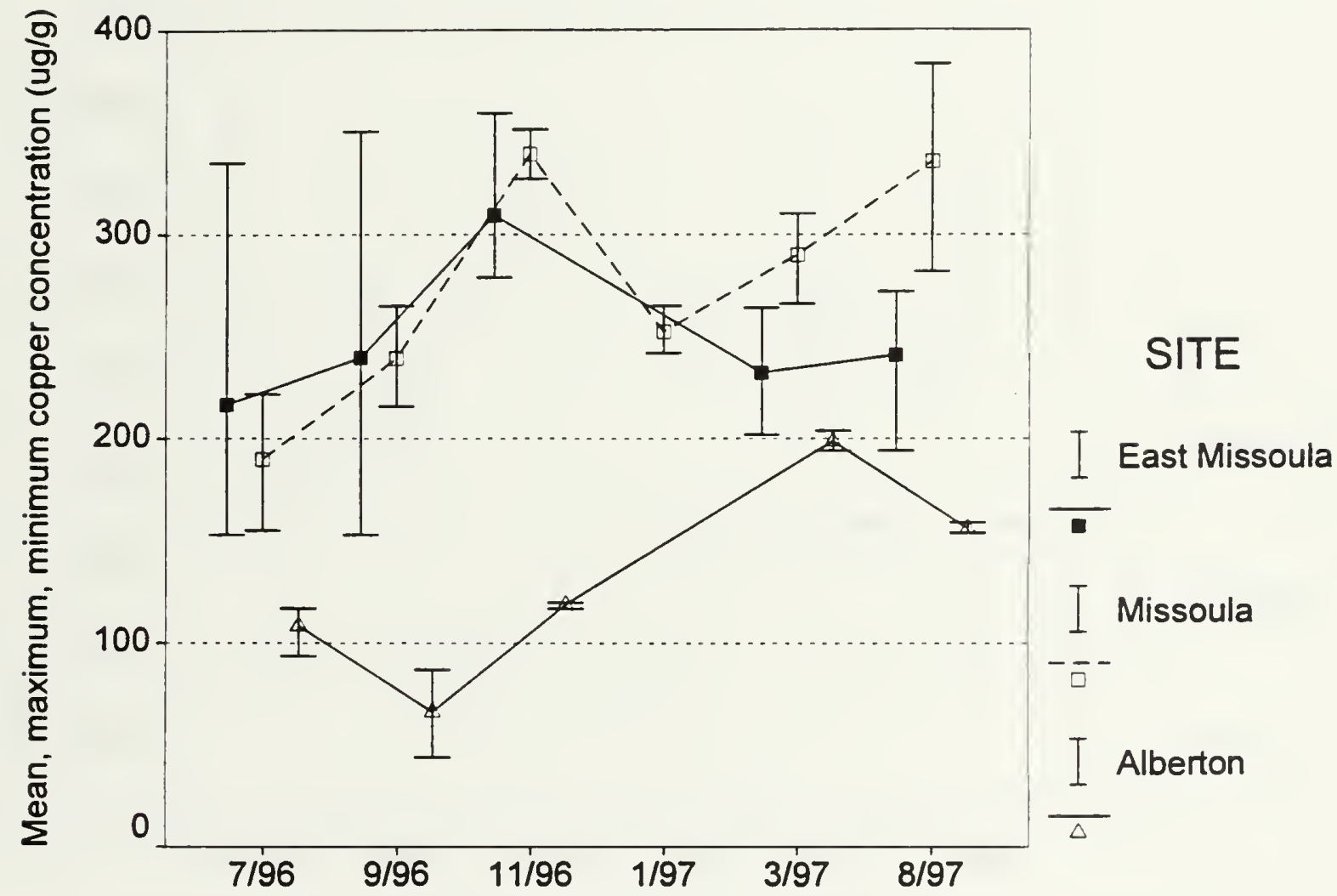

Figure 1. Copper concentrations (ug/g dry weight) in fine-grained bed sediments of the Clark Fork River at three sites. 



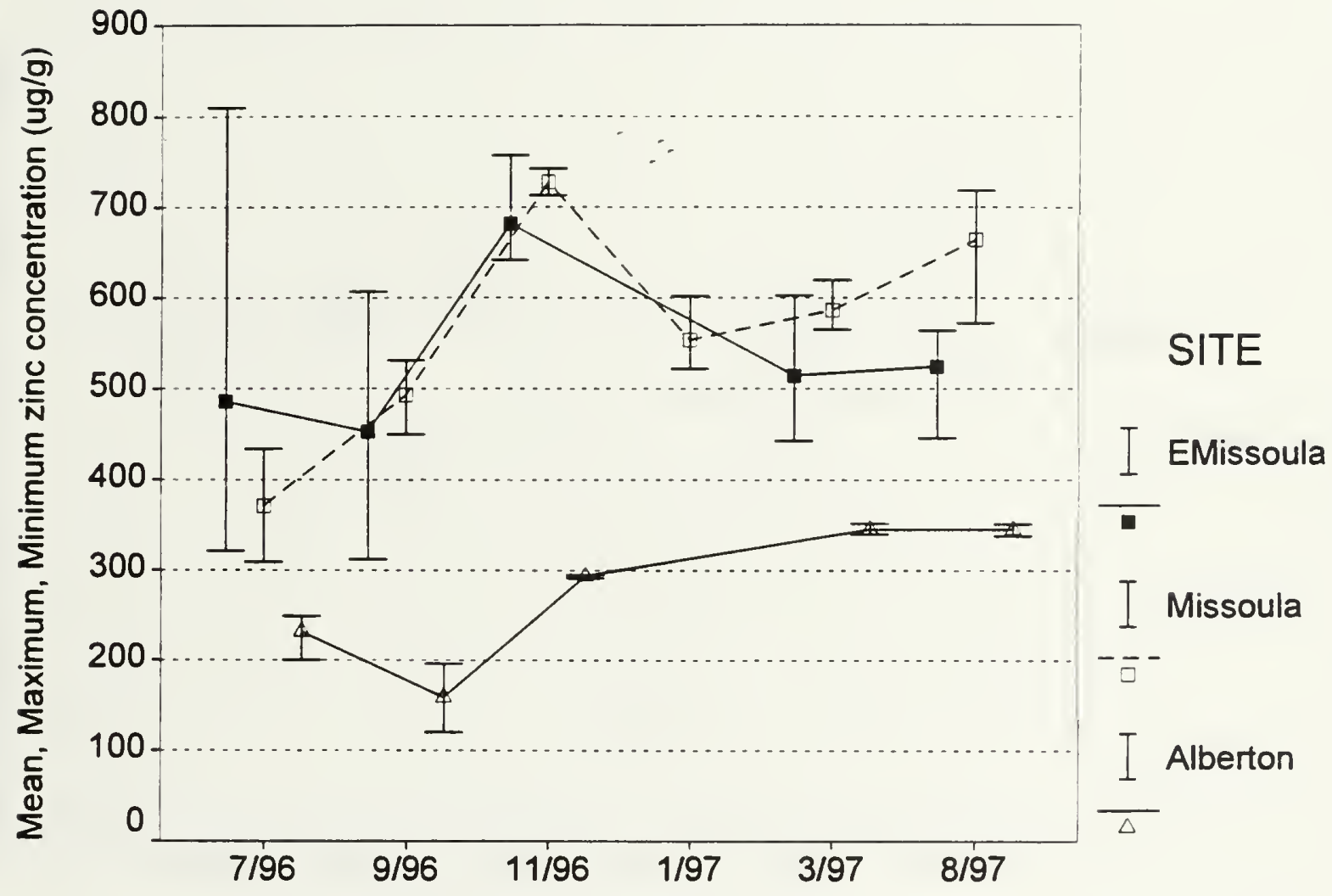

Figure 2. Zinc concentrations (ug/g dry weight) in fine-grained bed sediments of the Clark Fork River at three sites. 



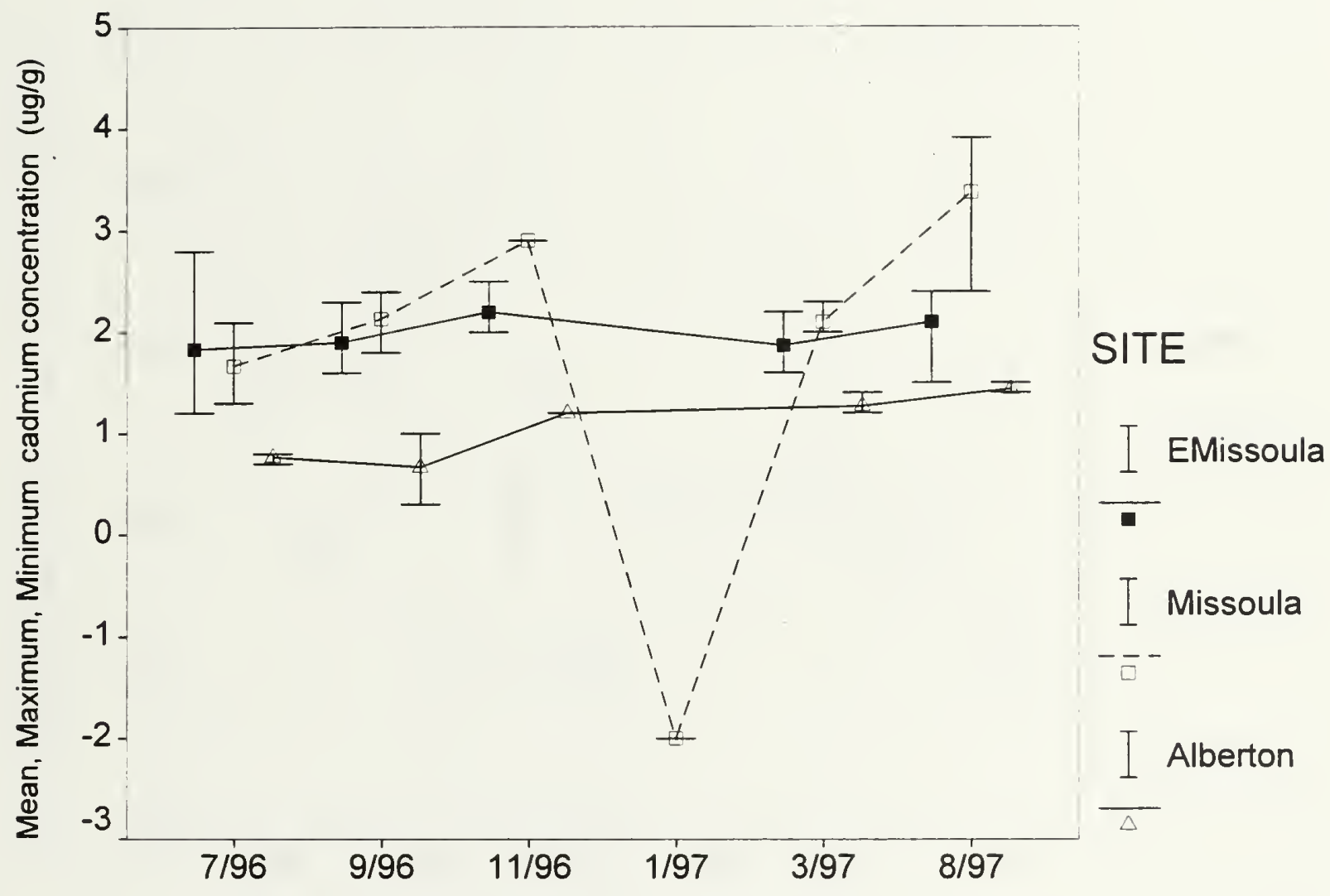

Figure 3. Cadmium (ug/g dry wt) in fine-grained bed sediments. Negative value indicates that concentration was below detection limit. 



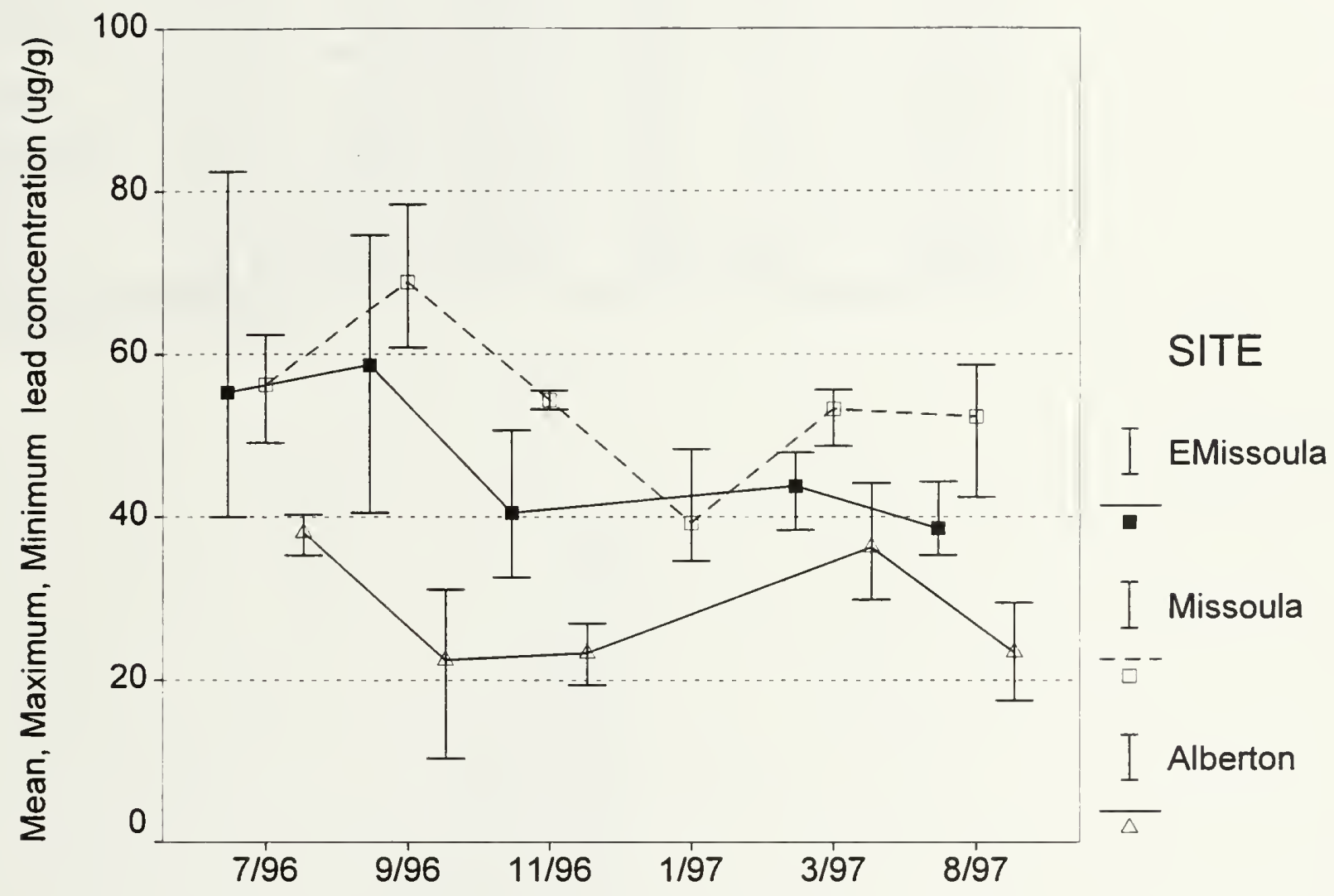

Figure 4. Lead concentrations (ug/g dry wt) in fine-grained bed sediments of the Clark Fork River at three sites. 



\begin{tabular}{||l|c|c|c|c|c|c||}
\hline \hline \multirow{2}{*}{$\begin{array}{r}\text { Table 7. Results of one-way ANOVA tests of the differences between mean metal } \\
\text { concentrations in fine-grained sediments at each site over time. In the } \\
\text { case where homogeneity of variance test failed, significance level is based } \\
\text { on the Kruskal Wallis (K-W) nonparmetric test. }\end{array}$} \\
\hline \hline & \multicolumn{2}{|c|}{ East Missoula } & \multicolumn{2}{|c|}{ Missoula } & \multicolumn{2}{c|}{ Alberton } \\
\cline { 2 - 9 } & $\mathrm{F}$ & Sig. & $\mathrm{F}$ & Sig. & $\mathrm{F}$ & Sig. \\
\hline Arsenic & 0.18 & 0.942 & 4.46 & $0.018^{*}$ & 80.3 & $0.000^{*}$ \\
\hline Cadmium & 0.30 & 0.870 & 59.1 & $0.000^{*}$ & $\mathrm{~K}-\mathrm{W}$ & $0.014^{*}$ \\
\hline Copper & 0.76 & 0.574 & 10.1 & $0.001^{*}$ & 56.4 & $0.000^{*}$ \\
\hline Manganese & 0.59 & 0.676 & $\mathrm{~K}-\mathrm{W}$ & 0.834 & 0.67 & 0.631 \\
\hline Lead & 1.25 & 0.351 & 5.32 & $0.010^{*}$ & 3.99 & $0.035^{*}$ \\
\hline Zinc & $\mathrm{K}-\mathrm{W}$ & 0.271 & 15.6 & $0.000^{*}$ & 42.2 & $0.000^{*}$ \\
\hline
\end{tabular}

*Significant at $\mathrm{P}<0.05$ level 



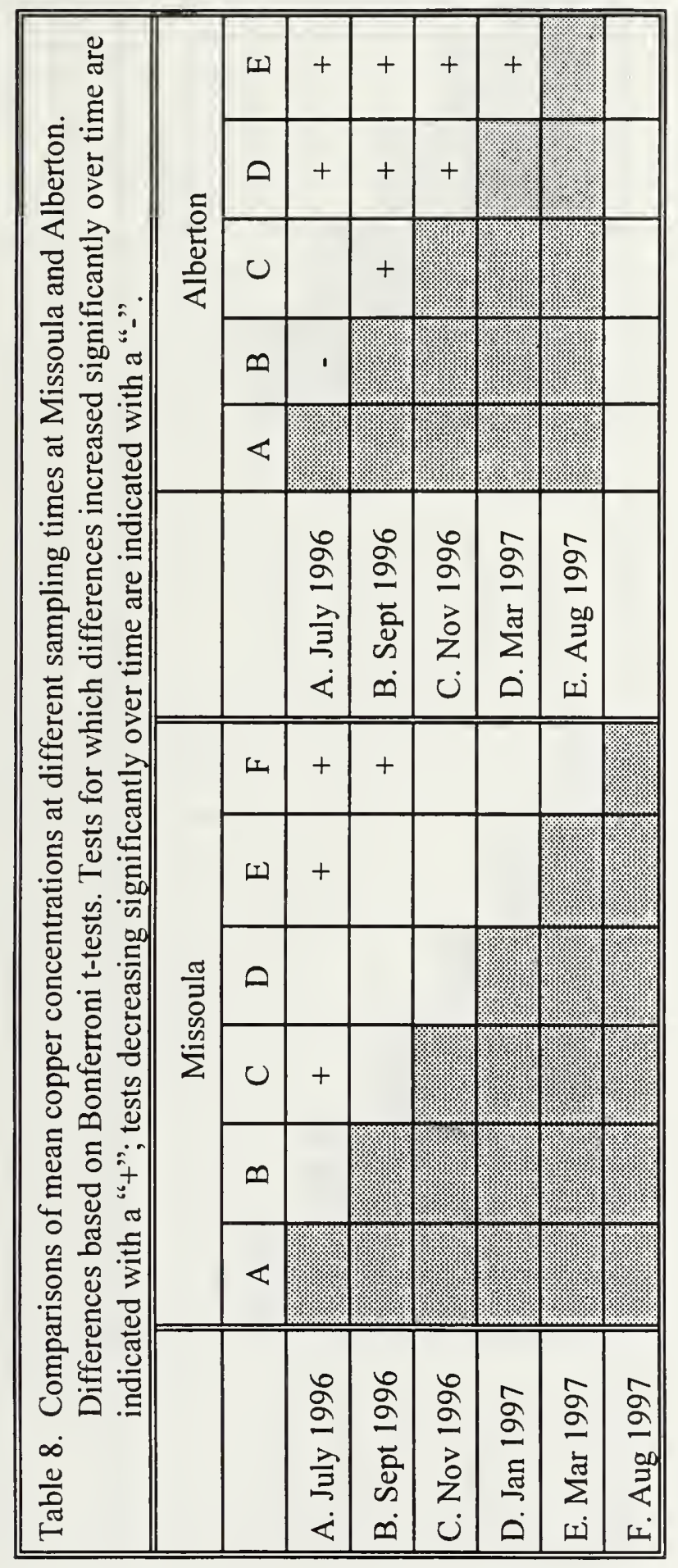





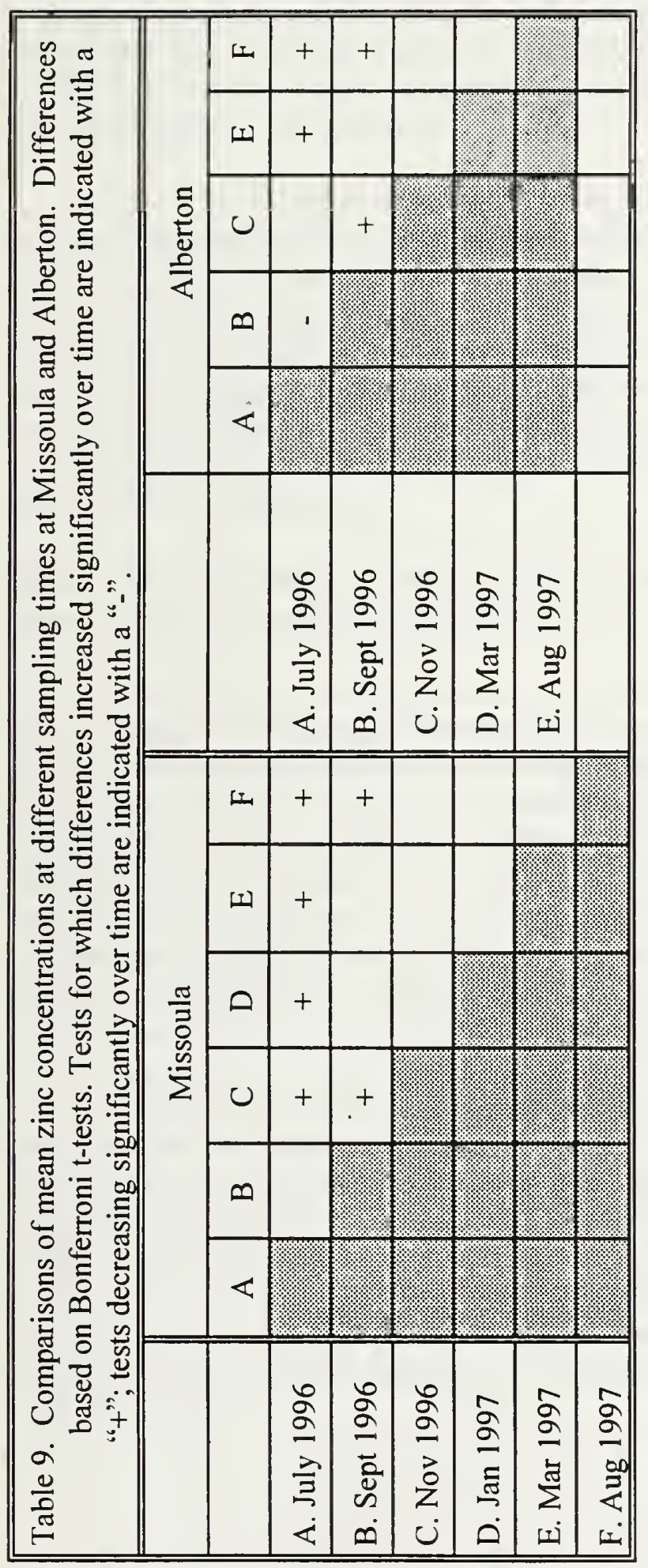



still moving into and through the other sites. However, it is also possible that these trends were due to or influenced by unique or different conditions at each site which might affect the metal concentrations. Boggs (1994) suggested that such conditions might include differences in streamflow, sediment deposition, sediment size fractions, organic matter content, metal-oxide content, and proportions of oxidized to reduced sediments. A further concern is that we may have committed Type I or Type II errors in our statistical analysis; the error being due to the inherent variability of sediment metal concentrations or perhaps an inappropriate temporal scale within which we sampled (2-4 month intervals).

The high flows during spring runoff in 1997 apparently resulted in a much larger loading of metals to the Clark Fork River than had been recorded during the previous 12 years (Lambing 1998). However, based on samples taken for this study, there was no clear effect on concentrations of copper and zinc in sediments. As discussed above, there were no significant changes over time at East Missoula. Even at Missoula and Alberton, where the ANOVA test revealed significant changes, there was no difference in mean zinc concentrations at either site when comparing pre-runoff conditions (March 1997 samples) to post-runoff conditions (August 1997). For copper, no difference was seen at the Missoula site for the two time periods, while at Alberton, copper actually decreased from March to August 1997.

Metals in benthic insects. Although spatial and temporal trends were seen with all metals, the only metals subjected to statistical analysis were copper and zinc.

Spatial Patterns. The Hydropsyche species (H. cockerelli and H. occidentalis) displayed the most consistent drop in copper concentrations from East Missoula to Missoula and then to Alberton. For all dates combined, the mean copper concentration was 55.0 and $52.9 \mathrm{ug} / \mathrm{g}$ at East Missoula, decreasing to 40.5 and $35.6 \mathrm{ug} / \mathrm{g}$ at Missoula, and 29.7 and $28.3 \mathrm{ug} / \mathrm{g}$ at Alberton for $\mathrm{H}$. cockerelli and $H$. occidentalis, respectively (Tables 10,11 and 12). For Pteronarcys, mean copper concentrations were highest at East Missoula (71.0 ug/g) but similar at Missoula (52.4 ug/g) and Alberton (53.0 ug/g)(Table 13). Claassenia showed the least variation in copper between sites, ranging from a high of $48.4 \mathrm{ug} / \mathrm{g}$ at East Missoula to a low of $44.3 \mathrm{ug} / \mathrm{g}$ at Alberton (Table 14). Arctopsyche had the lowest copper concentrations of all species, decreasing from a high of $40.0 \mathrm{ug} / \mathrm{g}$ at East Missoula to a low of $18.0 \mathrm{ug} / \mathrm{g}$ at Alberton (Table 15).

The spatial patterns of zinc were generally similar to those of copper. Claassenia had the highest concentrations of all species, which were also low in variability between sites (ranging from a high of $179.3 \mathrm{ug} / \mathrm{g}$ at East Missoula to a low of $171.7 \mathrm{ug} / \mathrm{g}$ at Missoula). Pteronarcys also had high zinc levels at East Missoula (178.1 ug/g), but concentrations decreased to their lowest at Missoula (153.9 $\mathrm{ug} / \mathrm{g}$ ). The Hydropsyche species were quite similar: both had highest zinc levels at East Missoula (172.8 and $173.3 \mathrm{ug} / \mathrm{g}$ for $H$. occidentalis and $H$. cockerelli, respectively) and lowest levels at Alberton (136.0 and $121.2 \mathrm{ug} / \mathrm{g})$. Arctopsyche had the lowest zinc concentrations, but still showed a decrease in a downstream direction (148.0 ug/g at East Missoula, $121.3 \mathrm{ug} / \mathrm{g}$ at Missoula and 119.9 $\mathrm{ug} / \mathrm{g}$ at Alberton). 



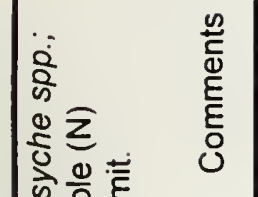

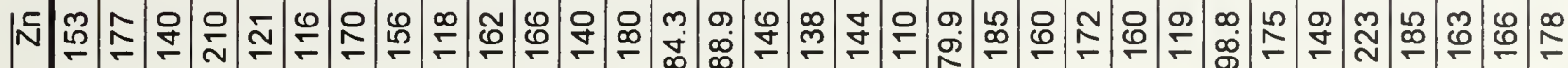

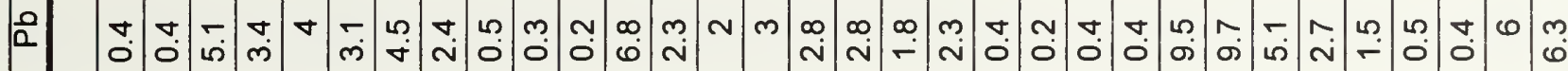

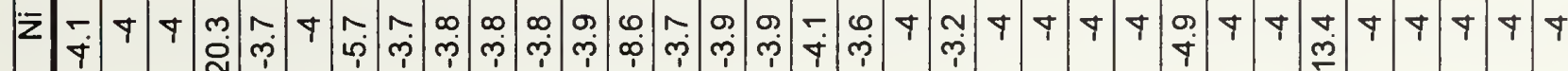
귈ㄷㄷㄹ 3

릉

Ğ II

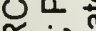
$\frac{\alpha}{\alpha} \cdot \frac{i}{\pi}$

ㅎํ웡 $\div$ 은

告 0

《

के

응 은

을 호

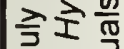

담 苛U 仓ั山.

ரํำ m J 远行: $\geq 0$. 뜨음 는 낭 는 矛 交 80 U ญ 둰 틍 응. 은 능 정 유공 은 号 U⿺辶 응드 을 뜡ㅇㅇㅇ

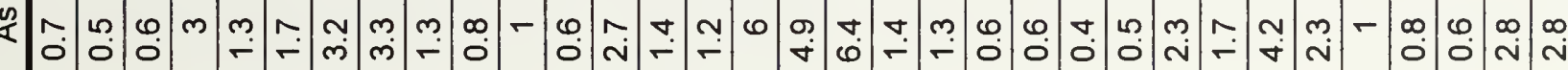

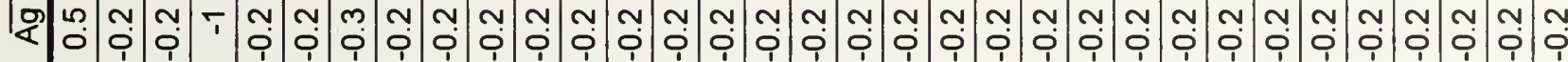

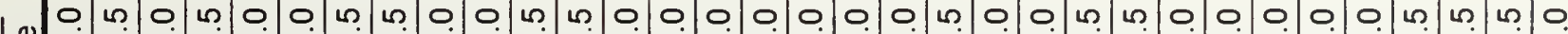
귓 N E ⿳艹

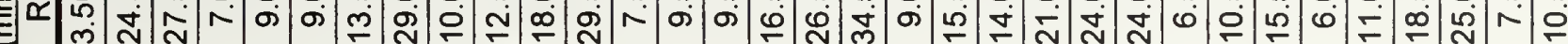

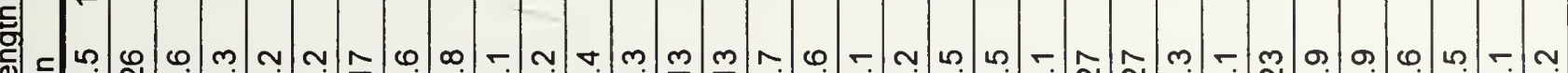
ब.

: 으

ஏ

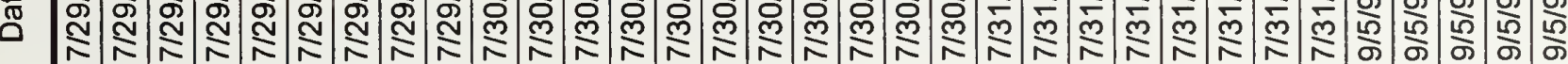
可 $\frac{0}{4} \frac{0}{0}$

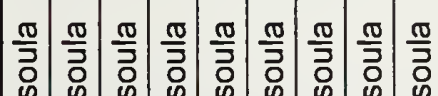



䔽

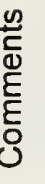

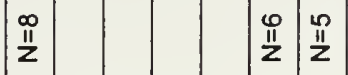

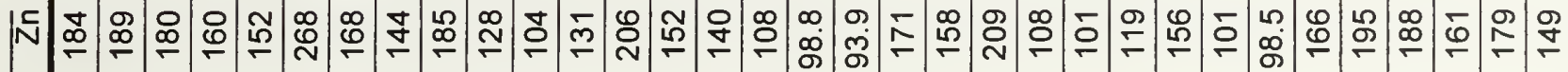

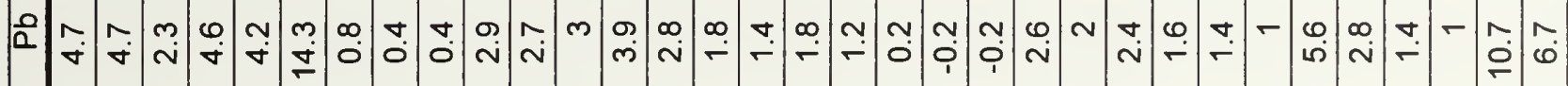

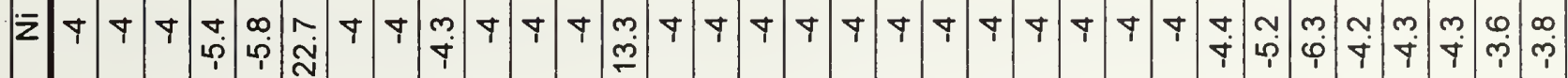

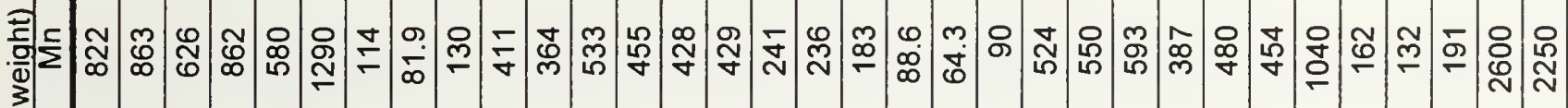
司告

들 :

穴

용

西 $\frac{0}{0}$

올 @

○్

dje - के

क्ष

$\stackrel{0}{\frac{1}{2}}$ is

골 $\frac{1}{\sqrt{3}}$

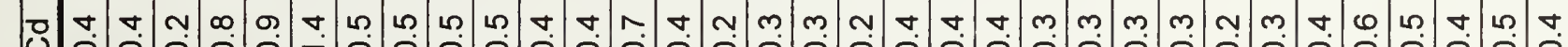
बi.

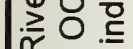

돈 흐음

닝 당

는

U

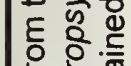

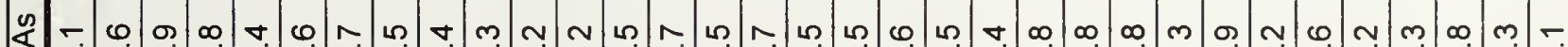

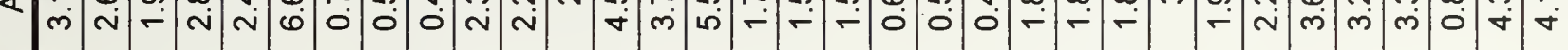


10 일 뒤 ह 일 응 至

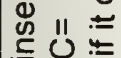

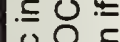

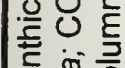

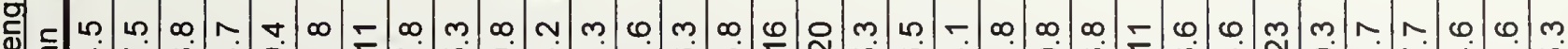
可

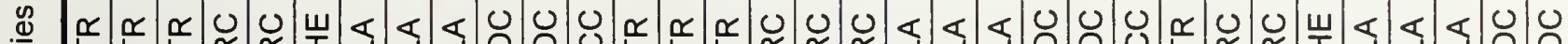
兽 它

凹

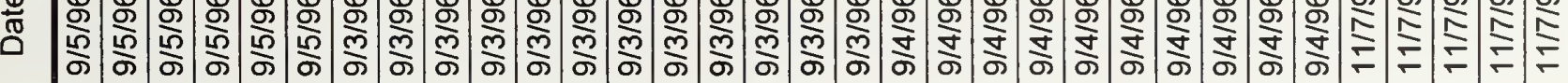
○े $\frac{\pi}{4} \frac{11}{0} \frac{0}{0}$

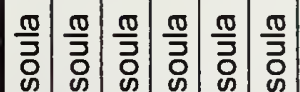

$\frac{\pi}{\bar{\partial}} \frac{\pi}{\bar{\partial}} \frac{\pi}{\bar{\partial}} \frac{\pi}{\bar{\partial}}$ 




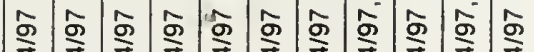

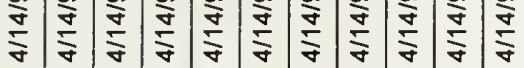

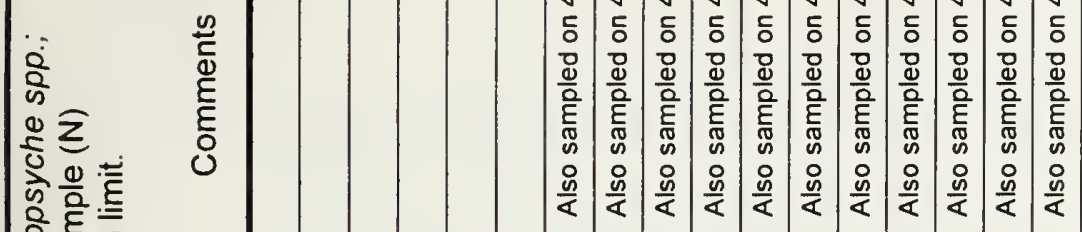

$\prod_{2} \frac{\pi}{2} \frac{\pi}{2}$

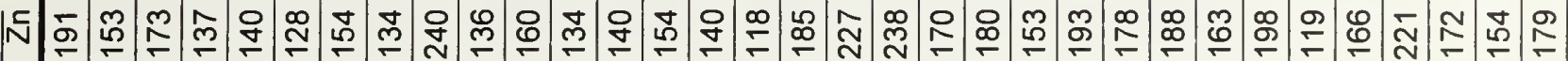

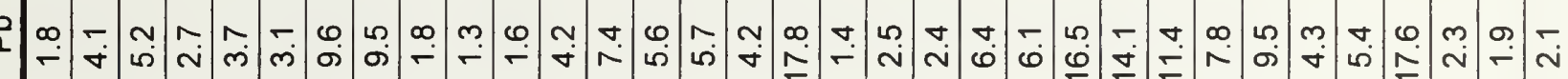
$\bar{z}$

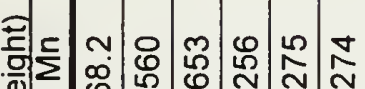

3

긍

नง ญิ กั

文足寒

11,

产

.

웡 ฏ

일

蕰

ㅎํㅇ ฏ

文贾

c่ के

융

준

:

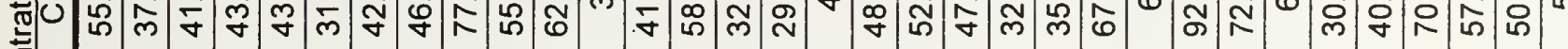

ปั่

J

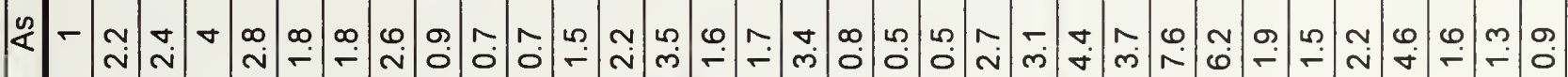
足

N

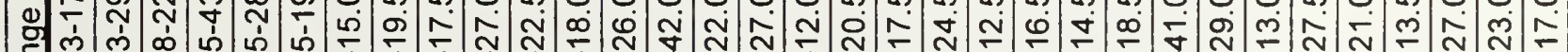

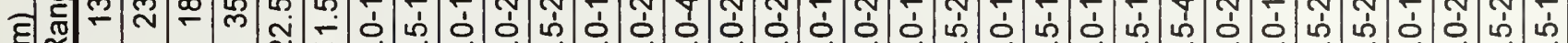

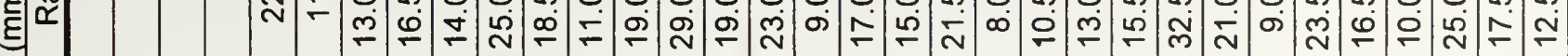

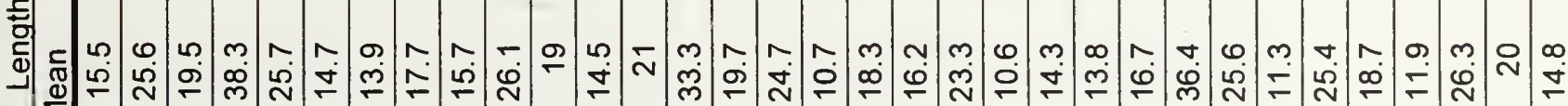
on 언 이다. . 용 돈 ज एक वे 응

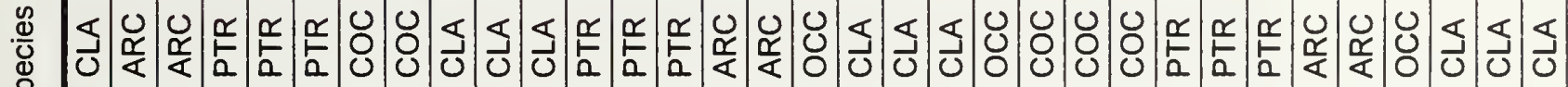
के

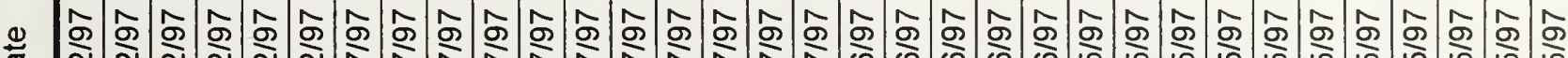

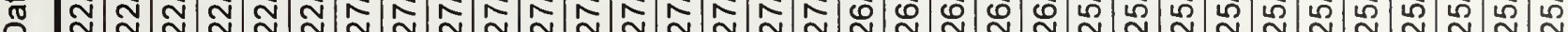

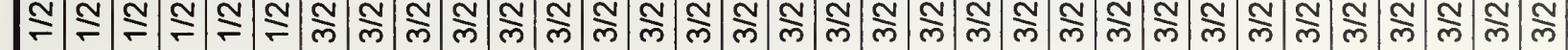

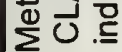





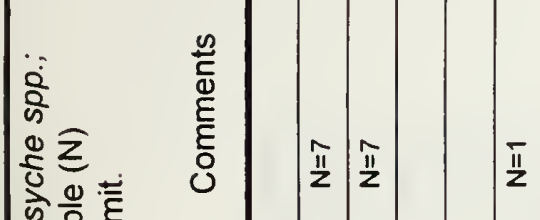

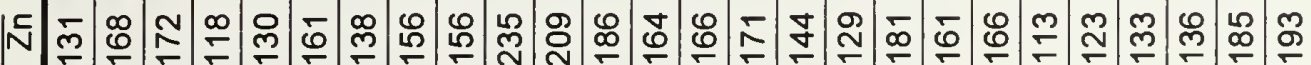
ब $0 \frac{0}{0}$ ป Nㅡㅇ III

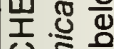
ํํㅇ i马 징 कृष के

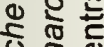
ธิ

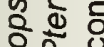
웡 这坚

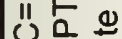
的 要

กิ รั 웡 ฏ $\div$ U⿺ 万ิ 궁

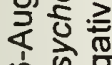
के क्ष 응

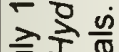

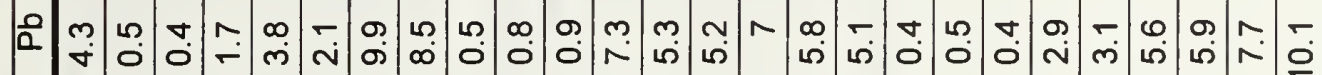
z

굼도

3

긍

대난

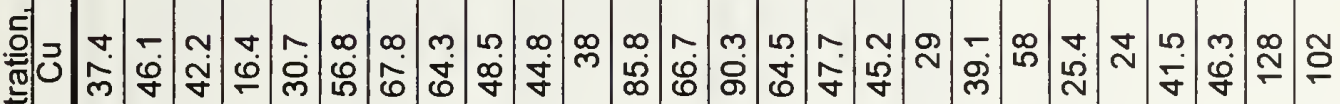
등

১ิ่

ठ 万ाI एँ 으모.․․․

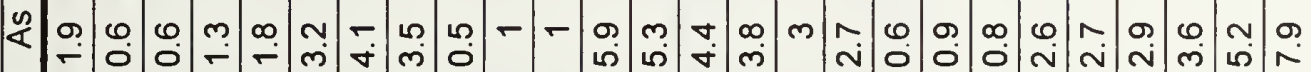
돈 능 $\frac{10}{10}$ 空 它 0 के

है क्ष 은 홍 $\frac{1}{\sqrt{2}}$ 용소잉

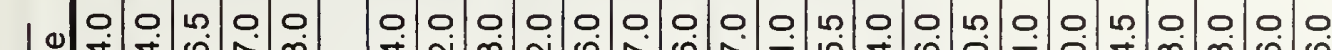
g ह है

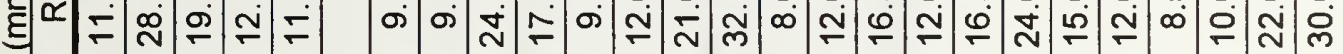

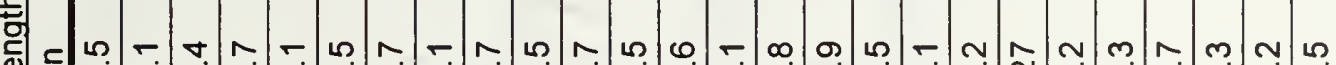

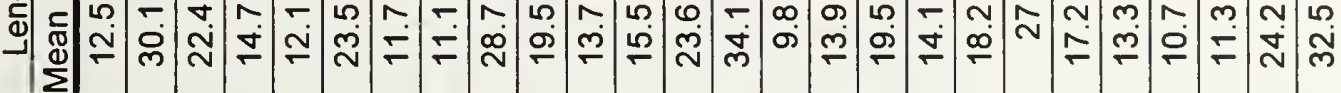

$\stackrel{\mathscr{\omega}}{U}$ O

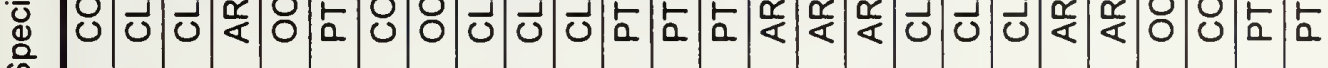

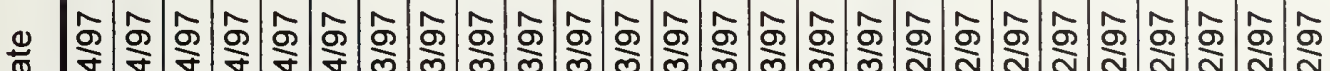

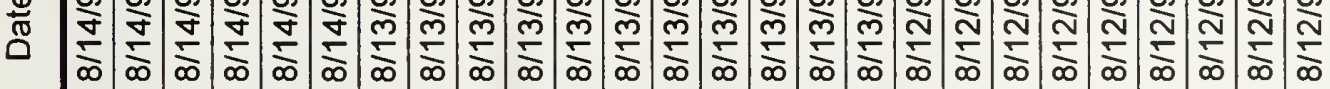

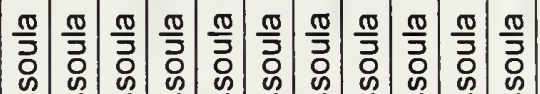





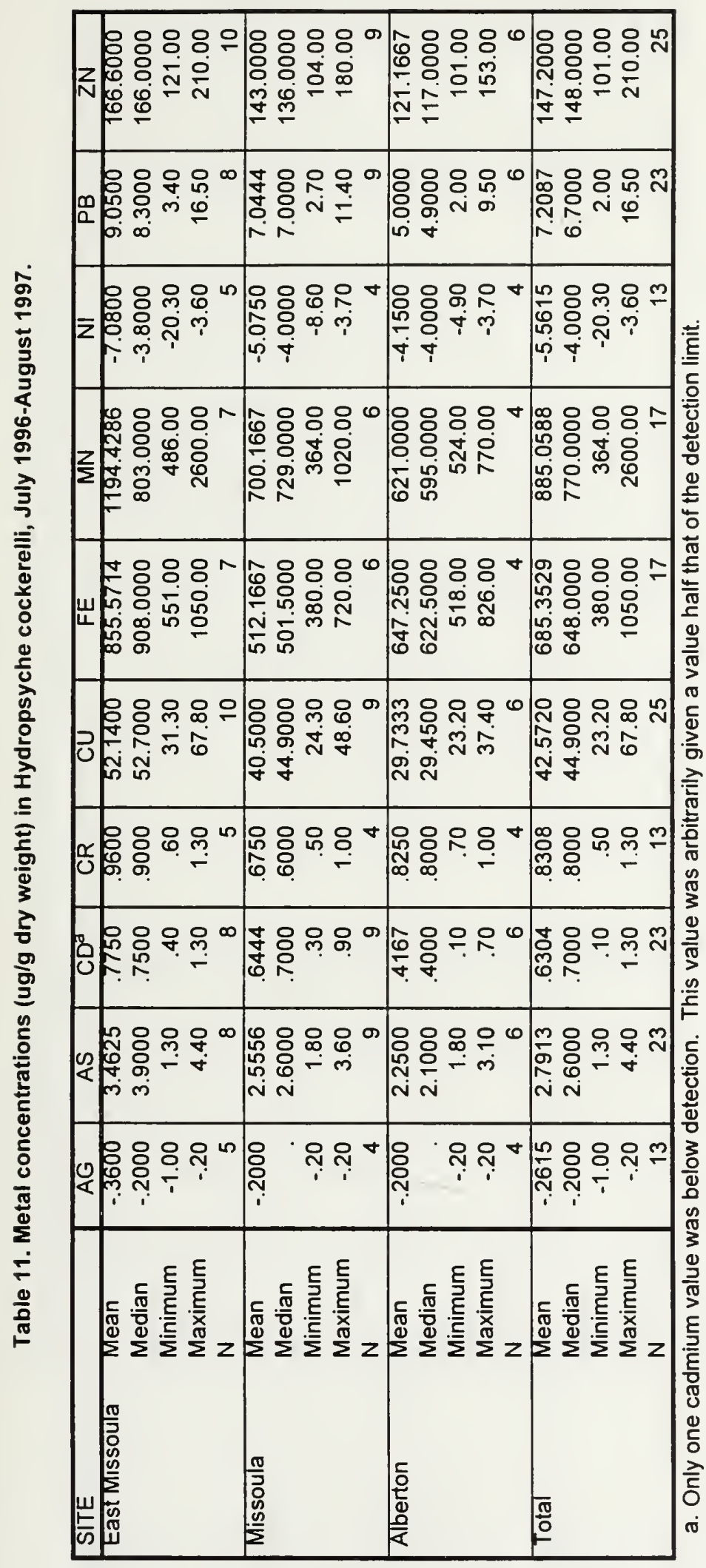




\begin{tabular}{|c|c|c|c|c|}
\hline$Z_{N}$ & 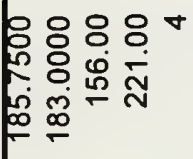 & 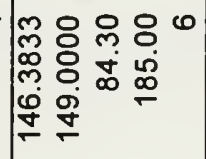 & 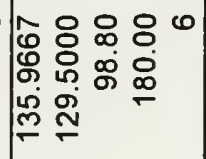 & $\mid \begin{array}{l}\infty \\
\infty \\
\infty\end{array}$ \\
\hline 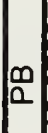 & 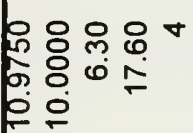 & 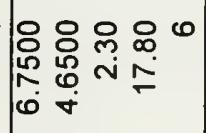 & 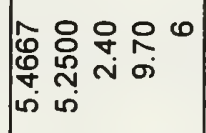 & 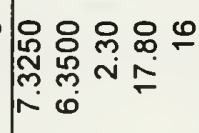 \\
\hline $\bar{z}$ & $\begin{array}{l}8 \\
8 \\
\\
\end{array}$ & $\begin{array}{llll}m & 8 & 0 & 0 \\
m & 8 & 0 \\
m & 0 & + & p \\
m & + & \end{array}$ & 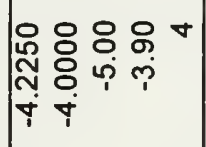 & 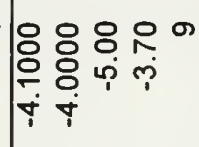 \\
\hline$z$ & 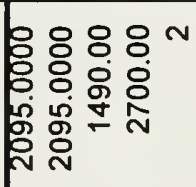 & 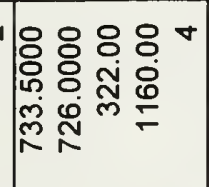 & 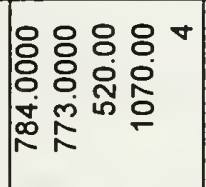 & 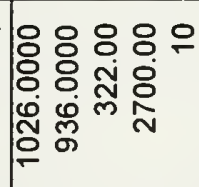 \\
\hline$w$ & 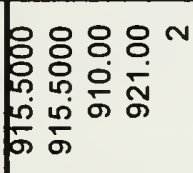 & 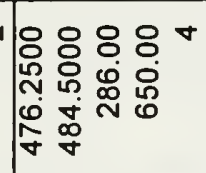 & 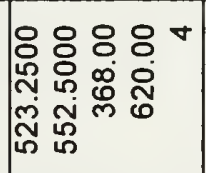 & 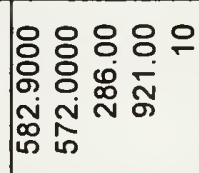 \\
\hline & 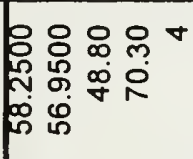 & 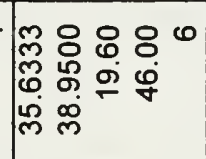 & 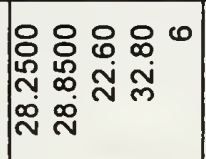 & 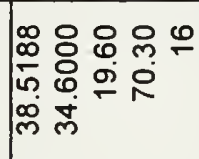 \\
\hline$\frac{x}{0}$ & 居品 & 용 용요 & 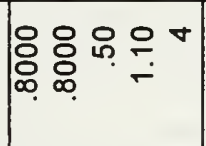 & 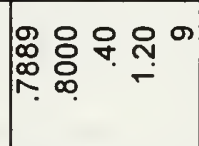 \\
\hline 8 & 尼 & 迢 응 웅 웅 & 음 율 & 佫 \\
\hline 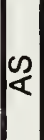 & 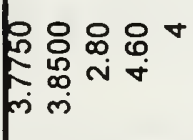 & 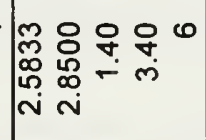 & 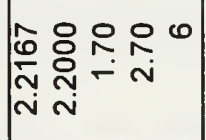 & 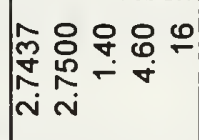 \\
\hline$\left|\begin{array}{l}0 \\
<\end{array}\right|$ & $\overbrace{}^{8}$ ำ ำ & 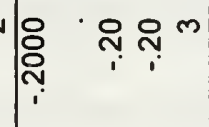 & 品 & 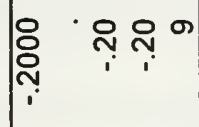 \\
\hline & 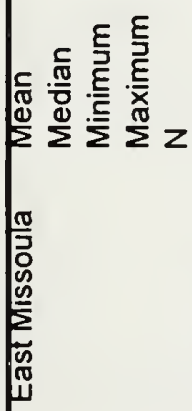 & 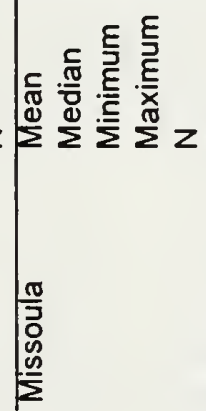 & 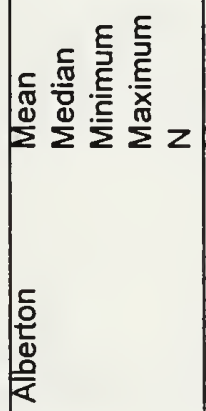 & 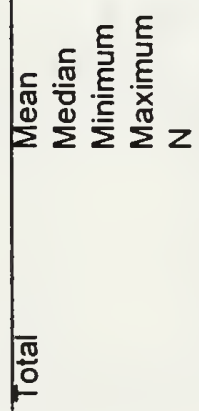 \\
\hline
\end{tabular}





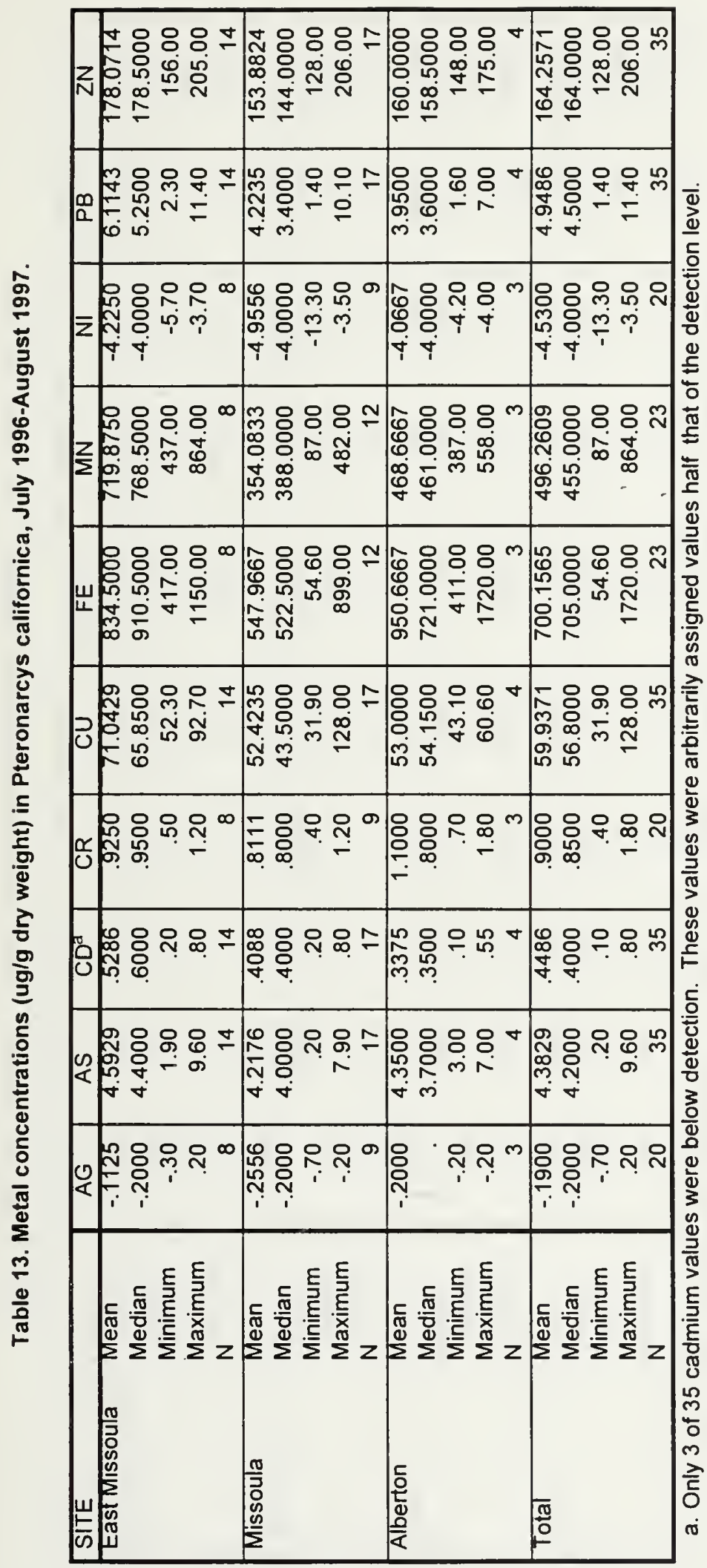





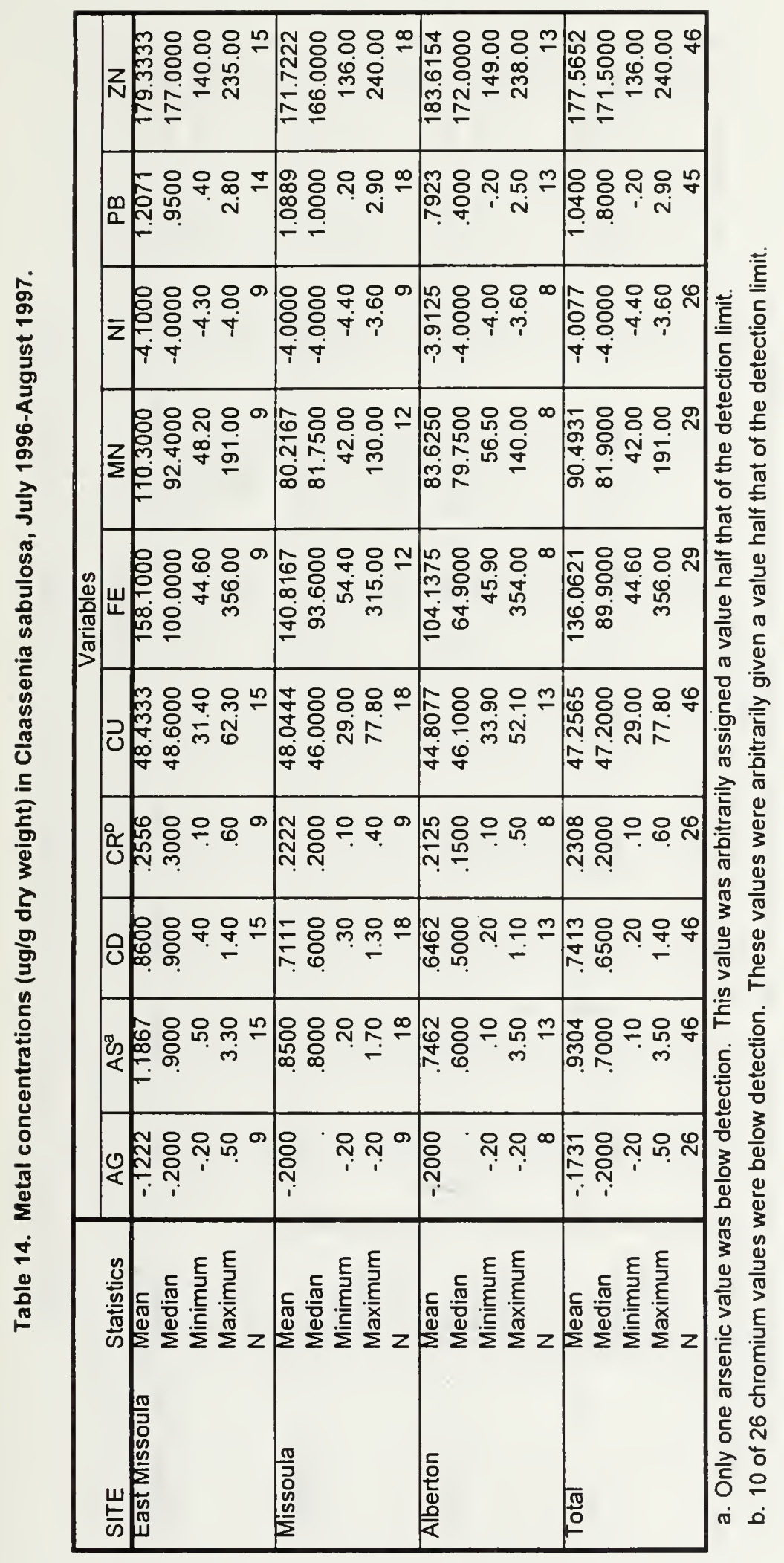





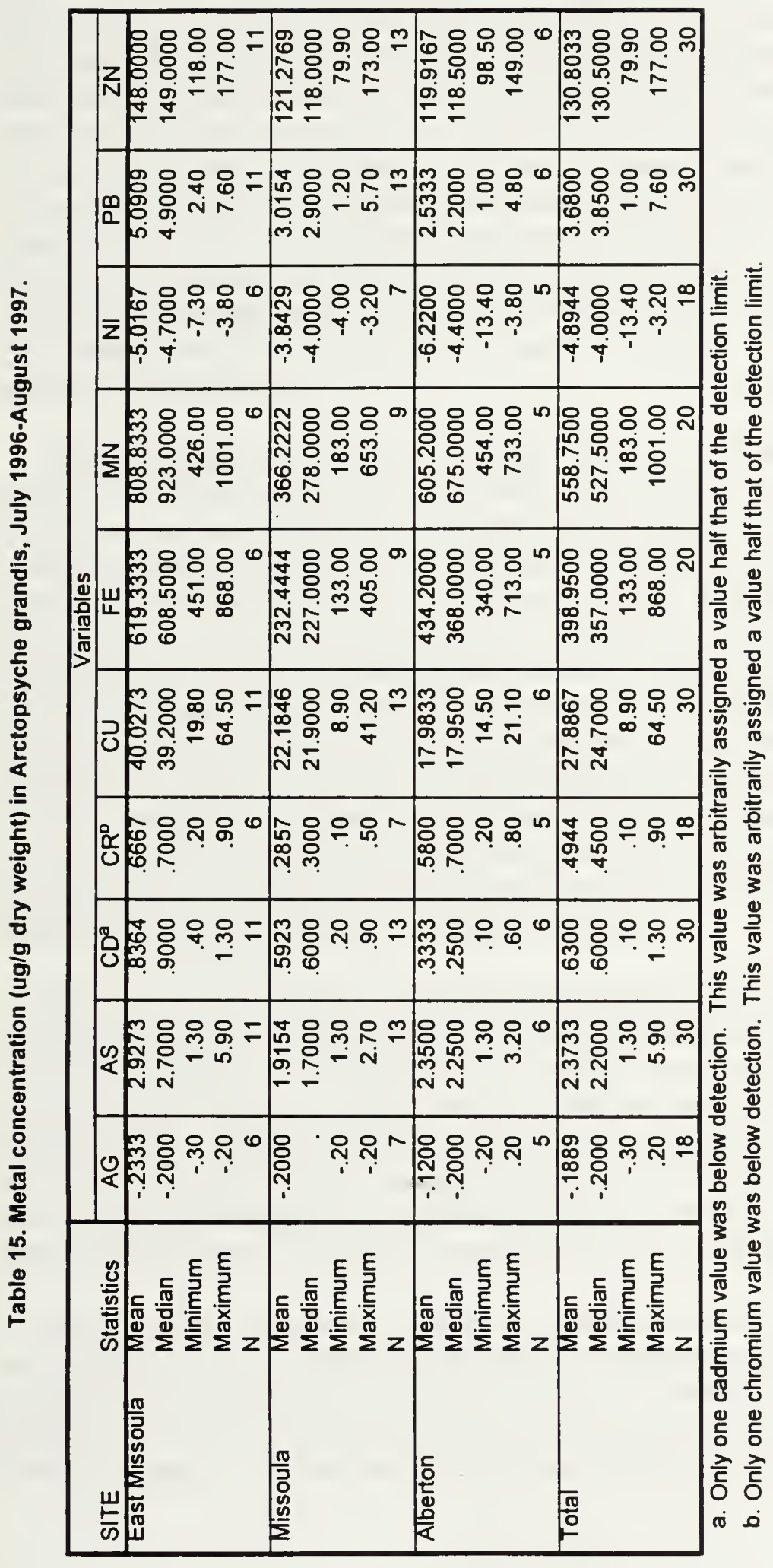



Statistical analysis of these data with one-way ANOVA showed that for all species but Claassenia we can reject the null hypothesis (at the $\mathrm{P}=0.05$ level) that the mean copper concentrations are the same at the three sites (Table 16). For zinc, the null hypothesis was rejected in Pteronarcys, H.Cockerelli, and Arctopsyche, but not H. occidentalis and Claassenia. In all cases where the null hypothesis was rejected, it was because of differences between the high mean values at the East Missoula site and lower values at one of the other sites. Pairwise comparisons showed that the East Missoula site had a significantly greater mean copper value than Missoula for Pteronarcys, both Hydropsyche species, and Arctopsyche (Table 17). Pteronarcys, H. cockerelli and Arctopsyche also had significantly higher mean concentrations of zinc at East Missoula than at Missoula. Copper concentrations were also significantly higher at East Missoula than Alberton for both Hydropsyche species and Arctopsyche; for zinc, only H. cockerelli was significantly higher at East Missoula than Alberton. In no case was the mean copper or zinc concentrations at Missoula significantly different than Alberton.

Temporal Patterns. Insects were sampled five times at East Missoula and Alberton, and six times at Missoula during the thirteen months of the study. This was done in order to identify changes in metal concentrations in insects that could result from significant hydrologic events in the drainage or changes in Milltown Dam operation. This type of evaluation must consider the periods of emergence of the insects being sampled and account for the different cohorts for species living longer than one year (e.g. three years for Pteronarcys). Consequently, we have restricted our analysis of temporal trends to those situations where the age of the insects is clearly understood. We have used length-frequency analysis as the technique for estimating the age of animals. For example, $H$. cockerelli larva at the Missoula site were close to emerging on March 27, 1997 when lengths ranged from 13.0-19.5 mm. When this species was sampled five months later on August 12, 1997, the lengths ranged from 10.0-13.0 mm, which we assumed to be from a new generation of animals. Also, we have not included Claassenia in this analysis because it may have some ability to regulate copper (Cain et al. 1992) and therefore seems to be a poor barometer of changes in the copper levels in the physical media (water, sediment).

Pteronarcys was the only species for which we were able to sample individuals that had lived through the February 1996 ice-out event. These individuals were first sampled in July 1996 as 2ndand 3rd-year animals. A comparison of the metal concentrations in these animals with younger animals born during or after high water in 1996 can serve to isolate some of the effects of the February event. Results show that the 1st-year animals, sampled in September or November 1996, had similar or higher levels of both copper or zinc (Table 18). This suggests that the older Pteronarcys animals did not have unexpectedly high levels of copper and zinc, and if there were any lingering effects from the February event, they were not manifested as high body burdens of metals.

Pteronarcys was also the only species we sampled that could be used to evaluate whether there were changes in copper and zinc concentrations in animals that lived through the 1997 runoff. This comparison was possible for a combination of first- and second-year animals at Missoula and East Missoula (Table 19). At East Missoula, the mean concentrations of the metals changed little from March to August: copper increased slightly from $68.8 \mathrm{ug} / \mathrm{g}$ to $80.9 \mathrm{ug} / \mathrm{g}$, while zinc decreased from 

Table 16. Results of one-way ANOVA tests of the differences between mean copper and zinc concentrations at the three sites.

\begin{tabular}{|c|c|c|c|c|c|c|c|c|c|c|}
\hline & \multicolumn{2}{|c|}{$\begin{array}{l}\text { Pteronarcys } \\
\text { californica }\end{array}$} & \multicolumn{2}{|c|}{$\begin{array}{l}\text { Hydropsyche } \\
\text { cockerelli }\end{array}$} & \multicolumn{2}{|c|}{$\begin{array}{l}\text { Hydropsyche } \\
\text { occidentalis }\end{array}$} & \multicolumn{2}{|c|}{$\begin{array}{l}\text { Arctopsyche } \\
\text { grandis }\end{array}$} & \multicolumn{2}{|c|}{$\begin{array}{l}\text { Claassenia } \\
\text { sabulosa }\end{array}$} \\
\hline & $\mathrm{F}$ & Sig. & $\mathrm{F}$ & Sig. & $\mathrm{F}$ & Sig. & $\mathrm{F}$ & Sig. & $\mathrm{F}$ & Sig. \\
\hline Copper & 3.7 & 0.035 & 13.5 & 0.000 & 7.6 & 0.006 & 12.3 & 0.000 & 0.8 & 0.473 \\
\hline Zinc & 6.4 & 0.005 & 9.0 & 0.002 & 1.6 & 0.239 & 5.1 & 0.013 & 0.9 & 0.404 \\
\hline
\end{tabular}





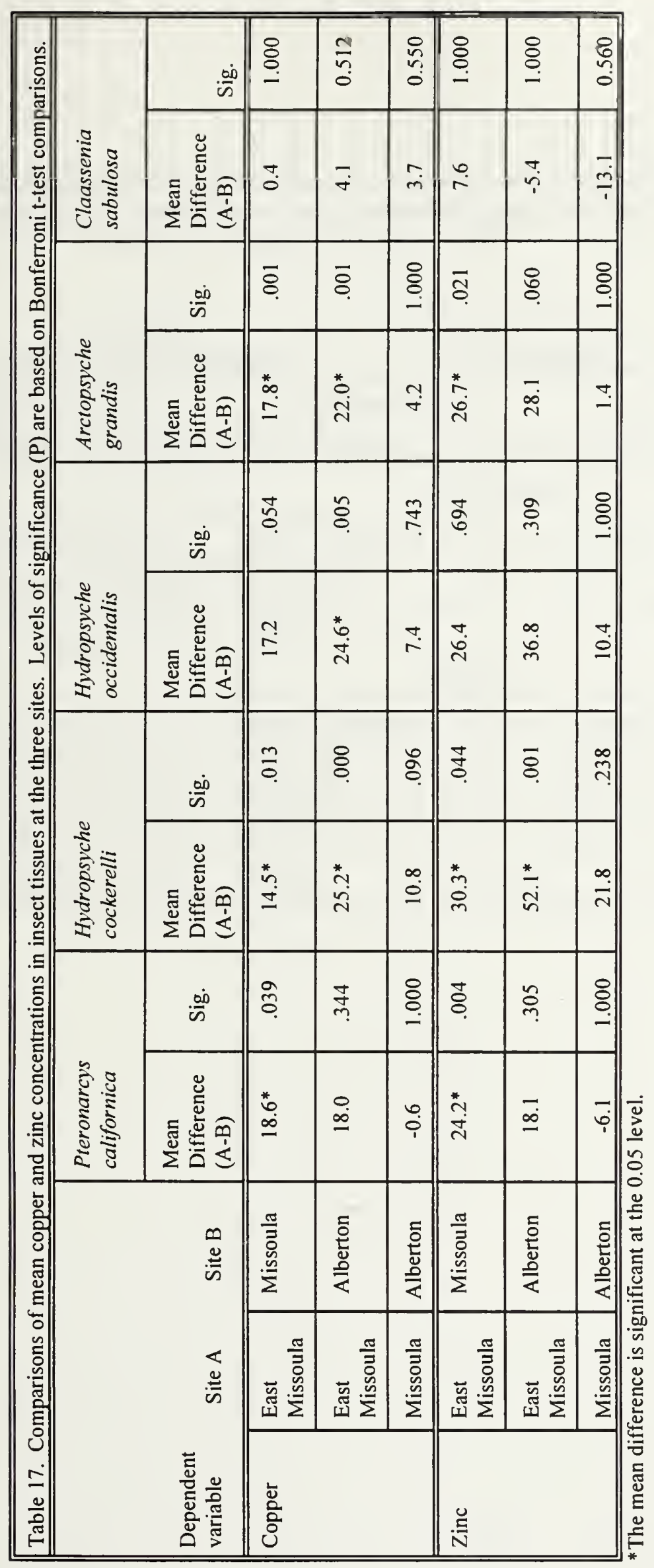





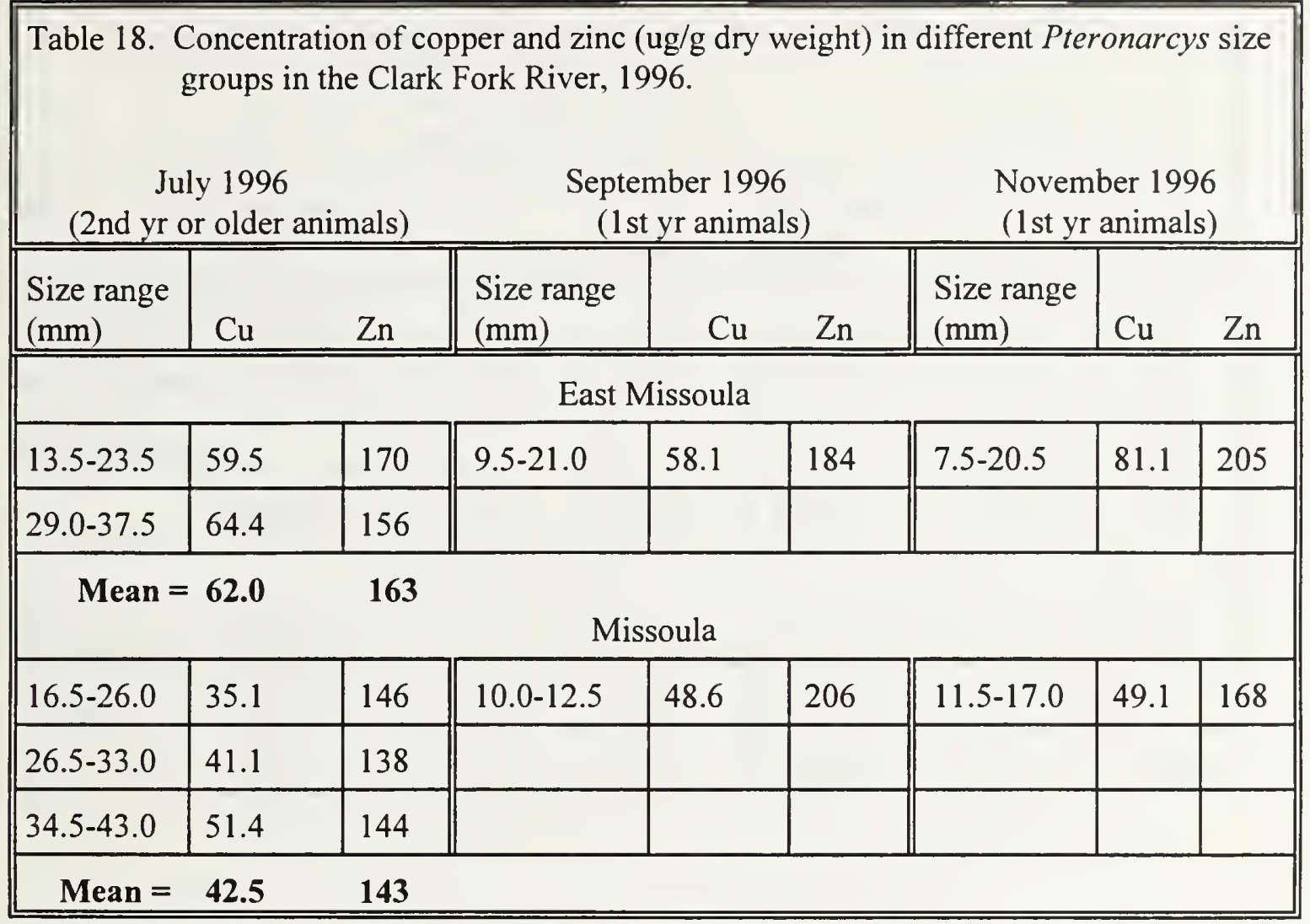



Table 19. Comparison of copper and zinc concentrations (ug/g dry wt) in different size groups of Pteronarcys before and after exposure to runoff in spring 1997.

\begin{tabular}{|l|l|c|c||l|l|l||}
\cline { 2 - 7 } & \multicolumn{3}{c|}{ March 1997} & \multicolumn{3}{c||}{ August 1997 } \\
\hline Site & $\begin{array}{l}\text { Size range } \\
(\mathrm{mm})\end{array}$ & $\mathrm{Cu}$ & $\mathrm{Zn}$ & $\begin{array}{l}\text { Size range } \\
(\mathrm{mm})\end{array}$ & $\mathrm{Cu}$ & $\mathrm{Zn}$ \\
\hline \hline East Missoula & $9.0-13.0$ & 65 & 198 & $12.0-17.0$ & 85.8 & 186 \\
\hline East Missoula & $21.0-29.0$ & 72.7 & 163 & $21.0-26.0$ & 66.7 & 164 \\
\hline East Missoula & & & & $32.5-37.0$ & 90.3 & 166 \\
\hline & Mean $=$ & $\mathbf{6 8 . 8}$ & $\mathbf{1 8 0 . 5}$ & Mean $=$ & $\mathbf{8 0 . 9}$ & 172 \\
\hline & & & & & 128 & 185 \\
\hline Missoula & $11.0-18.0$ & 37 & 134 & $22.0-26.0$ & 128 & 193 \\
\hline Missoula & $19.0-26.0$ & 41.1 & 140 & $30.0-36.0$ & 102 & 188 \\
\hline
\end{tabular}



$180.5 \mathrm{ug} / \mathrm{g}$ to $172 \mathrm{ug} / \mathrm{g}$. This was in contrast to the trend at Missoula where copper concentrations increased markedly from 39 to $115 \mathrm{ug} / \mathrm{g}$ and the zinc increased from 137 to $188 \mathrm{ug} / \mathrm{g}$.

Another useful comparison that can be made is of the metal concentrations in animals born slightly before or during the runoff periods of 1996 and 1997. Any differences in metal concentrations can probably be attributed, at least in part, to differing amounts of exposure to metals in water and sediment during the runoff itself. This comparison was possible for Hydropsyche cockerelli and Arctopsyche at all sites. Four of the six comparisons for copper showed an increase from 1996, with an average increase of 32\% for H. cockerelli and 99\% for Arctopsyche for all three sites combined (Table 20). For zinc there was no obvious trend, as only three of six comparisons showed an increase over time. Furthermore, the average change in zinc concentration over time was a $-17 \%$ for $H$. cockerelli and $+12 \%$ for Arctopsyche. These results suggest that conditions were more conducive for the accumulation of copper, but not zinc, during the spring of 1997 than the spring of 1996.

Community composition of benthic invertebrates. Three Hess samples were collected from each site in July, September and November of 1996 and again in August of 1997. Ice conditions in January 1997 prevented us from sampling all but the Missoula site, while rising water in March 1997 precluded sampling at all sites.

The Hess samples from the Missoula site were analyzed and summarized for this report. The total number of organisms averaged 257.0 per sample in July 1996, rose to 423.3 in September and reached a peak of 809.7 in November. Numbers dropped substantially in January (176.7) before rising to 399.7 in August 1997 (Figure 5, Tables 21-25). This pattern is generally consistent with that described by Hynes (1970) for stream-dwelling insects in temperate regions. This pattern is one in which most insects reach their peak numbers in late fall-early winter as a result of the growth and recruitment of young from reproduction the previous summer. Throughout the winter, numbers decline as a result of death, and by spring additional reductions result from insect emergence. Minimum numbers are then typically reached in late spring. On the Clark Fork there was a precipitous drop in just two months from November to January. Whether or not this is typical is unknown, but the severe ice conditions and scour on the river at the time may have had an effect on the densities of near-shore dwellers. Regardless of the cause for the low numbers in January, the populations subsequently increased to the point that the August 1997 numbers (399.7) were actually somewhat higher than the July 1996 numbers (257.0).

This seasonal pattern in abundance described by Hynes (1970) was followed at the Missoula site by Dipterans, caddisflies and stoneflies, but not by mayflies. Mayflies had a density of 174.3 per Hess sample in July 1996, but then dropped to 69.7 in September and back up again to 174.7 in November. No obvious explanation can be provided for this pattern. Caddisflies were unusual in that their highest densities were reached in August 1997, at which time they were more than nine times more plentiful (259) than they were in July 1996 (27.7). Most of the difference between these two samples was due to the increase in numbers of one species (H.cockerelli) in August 1997. On that date, $H$. cockerelli made up $67.2 \%$ of the total caddisflies at the site, whereas in July 1996 the 


\begin{tabular}{|c|c|c|c|c|c|c|c|}
\hline \multicolumn{8}{|c|}{$\begin{array}{l}\text { Table 20. Comparison of copper and zinc concentrations (ug/g dry wt) in insects born before } \\
\text { or during spring runoff. }\end{array}$} \\
\hline & & \multicolumn{3}{|c|}{ July 1996} & \multicolumn{3}{|c|}{ August 1997} \\
\hline Site & Species & $\begin{array}{l}\text { Size range } \\
(\mathrm{mm})\end{array}$ & $\mathrm{Cu}$ & $\mathrm{Zn}$ & $\begin{array}{l}\text { Size range } \\
(\mathrm{mm})\end{array}$ & $\mathrm{Cu}$ & $\mathrm{Zn}$ \\
\hline E. Missoula & H. cockerelli & $7.0-11.5$ & 39.7 & 210 & $9.0-14.0$ & 67.8 & 136 \\
\hline Missoula & H. cockerelli & $7.0-15.0$ & 48.6 & 180 & $10.0-13.0$ & 46.3 & 136 \\
\hline Alberton & H. cockerelli & $6.5-14.0$ & 28.5 & 119 & $11.0-14.0$ & 37.4 & 131 \\
\hline \multicolumn{6}{|c|}{ Average change 1996 to $1997=$} & $+32 \%$ & $-17 \%$ \\
\hline E. Missoula & Arctopsyche & $10.0-16.0$ & 19.8 & 118 & $8.0-11.0$ & 64.5 & 171 \\
\hline Missoula & Arctopsyche & $9.0-14.0$ & 12.6 & 110 & $12.0-14.5$ & 24 & 123 \\
\hline Alberton & Arctopsyche & $6.0-14.0$ & 20.1 & 149 & $12.0-17.0$ & 16.4 & 118 \\
\hline \multicolumn{6}{|c|}{ Average change 1996 to $1997=$} & $+99 \%$ & $+12 \%$ \\
\hline
\end{tabular}





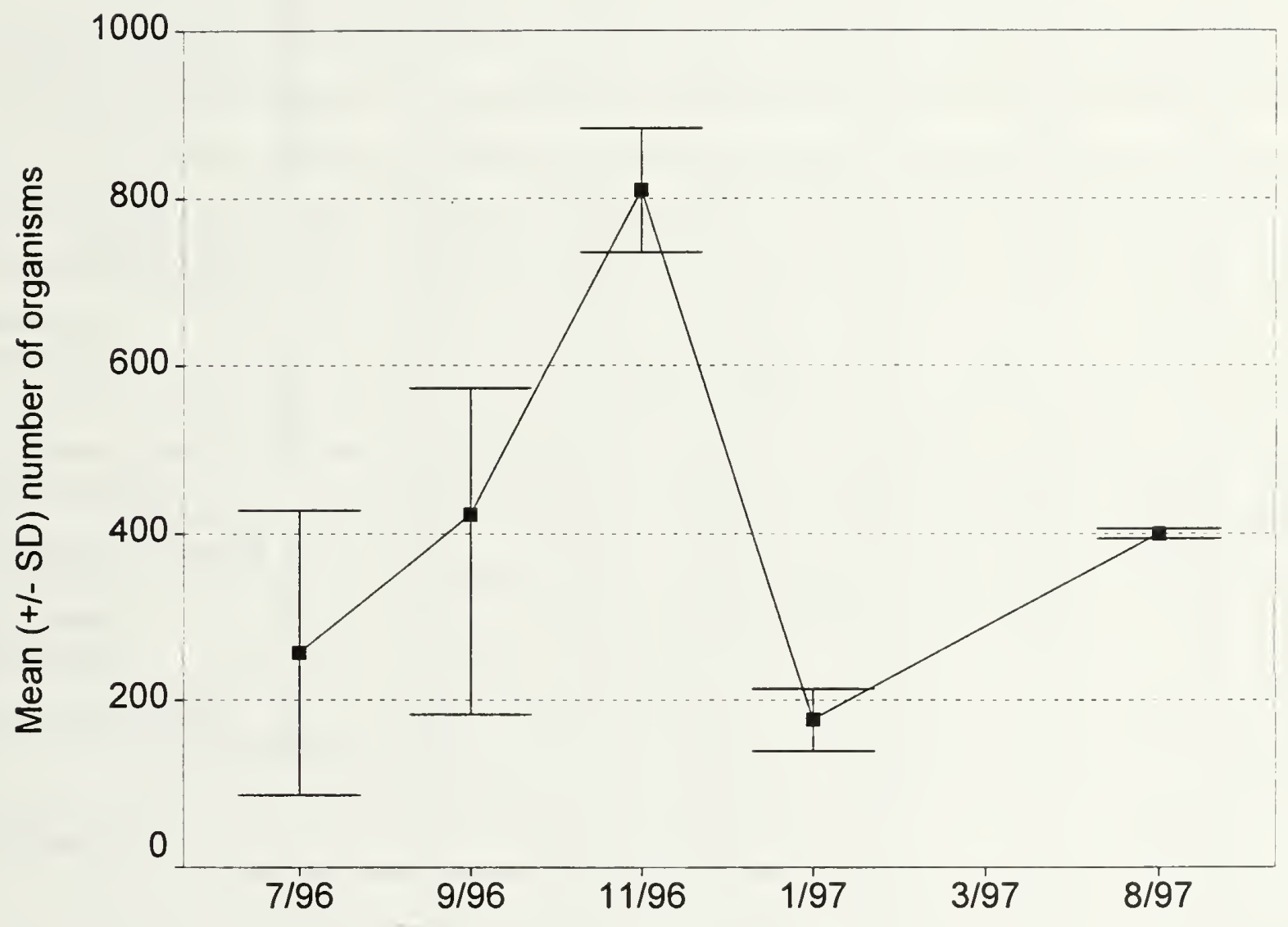

Figure 5. Number of benthic organisms per Hess sample from the Missoula site. $\mathrm{N}=4$ for $7 \& 9 / 96 ; \mathrm{N}=3$ for other dates. 



\begin{tabular}{|c|c|c|c|c|c|c|c|}
\hline Taxon & $\begin{array}{c}\text { Sample } \\
1 \\
\end{array}$ & $\begin{array}{c}\text { Sample } \\
2 \\
\end{array}$ & $\begin{array}{c}\text { Sample } \\
3 \\
\end{array}$ & $\begin{array}{c}\text { Sample } \\
4 \\
\end{array}$ & SUM & Mean & $\mathrm{SD}$ \\
\hline COLEOPTERA & 4 & 4 & 5 & 6 & 9 & 2.2 & 2.6 \\
\hline DIPTERA & 11 & 26 & 150 & 6 & 187 & 46.7 & 69.7 \\
\hline EPHEMEROPTERA & 95 & 109 & 301 & 192 & 697 & 174.3 & 94.7 \\
\hline PLECOPTERA & 2 & 1 & 7 & 11 & 21 & 5.2 & 4.6 \\
\hline Claassenia sabulosa & 1 & 0 & $\bullet$ & 3 & 9 & 2.3 & 2.2 \\
\hline $\begin{array}{l}\text { Pteronarcys } \\
\text { californica }\end{array}$ & 1 & 0 & 2 & 8 & 11 & 2.7 & 3.6 \\
\hline TRICHOPTERA & 24 & 12 & 40 & 35 & 111 & 27.7 & 12.4 \\
\hline Hydropsyche cockerelli & 2 & 1 & 6 & 2 & 11 & 2.7 & 2.2 \\
\hline $\begin{array}{l}\text { Hydropsyche } \\
\text { occidentalis }\end{array}$ & 4 & 2 & 10 & 12 & 28 & 7.0 & 4.8 \\
\hline Arctopsyche grandis & 3 & 1 & 1 & 4 & 9 & 2.2 & 1.5 \\
\hline AMPHIPODA & 0 & 0 & 1 & 11 & 1 & 0.3 & 0.5 \\
\hline GASTROPODA & II & 0 & 0 & 1 & 1 & 0.3 & 0.5 \\
\hline ANNELIDA & 0 & 0 & 0 & 1 & 1 & 0.3 & 0.5 \\
\hline TOTAL ORGANISMS & 132 & 152 & 504 & 240 & 1028 & 257.0 & 171.2 \\
\hline
\end{tabular}





\begin{tabular}{|c|c|c|c|c|c|c|c|}
\hline Taxon & Sample 1 & Sample 2 & Sample 4 & Sample 4 & SUM & Mean & $\mathrm{SD}$ \\
\hline COLEOPTERA & 5 & 7 & 10 & 11 & 33 & 8.3 & 2.8 \\
\hline DIPTERA & 90 & 158 & 251 & 119 & 623 & 155.7 & 68.6 \\
\hline EPHEMEROPTERA & 79 & 66 & 84 & 45 & 279 & 69.7 & 19.0 \\
\hline PLECOPTERA & 17 & 10 & 15 & 24 & 73 & 18.3 & 3.9 \\
\hline Claassenia sabulosa & 11 & 10 & 10 & 10 & 42 & 10.5 & 0.6 \\
\hline Pteronarcys californica & 6 & 7 & 5 & 10 & 28 & 7.8 & 2.2 \\
\hline TRICHOPTERA & 90 & 173 & 268 & 152 & 683 & 170.7 & 73.8 \\
\hline Hydropsyche cockerelli & 34 & 62 & 44 & 47 & 187 & 46.7 & 11.6 \\
\hline Hydropsyche occidentalis & 34 & 90 & 178 & 79 & 355 & 69.7 & 62.4 \\
\hline Arctopsyche grandis & 4 & 4 & 13 & 9 & 30 & 7.5 & 3.9 \\
\hline ANNELIDA & 2 & 0 & 0 & 0 & 2 & 0.5 & 1.0 \\
\hline TOTAL ORGANISMS & 288 & 421 & 633 & 351 & 1693 & 423.3 & 150.0 \\
\hline
\end{tabular}





\begin{tabular}{|c|c|c|c|c|c|c|}
\hline Taxon & Sample 1 & Sample 2 & Sample 3 & SUM & Mean & SD \\
\hline COLEOPTERA & 6 & 3 & 20 & 29 & 9.7 & 9.1 \\
\hline DIPTERA & 232 & 415 & 317 & 964 & 321.3 & 91.6 \\
\hline EPHEMEROPTERA & 128 & 210 & 186 & 524 & 174.7 & 42.1 \\
\hline PLECOPTERA & 75 & 70 & 116 & 261 & 87.0 & 25.2 \\
\hline Claassenia sabulosa & 22 & 12 & 26 & 60 & 20.0 & 7.2 \\
\hline Pteronarcys californica & 8 & 1 & 8 & 17 & 5.7 & 4.0 \\
\hline TRICHOPTERA & 291 & 128 & 239 & 650 & 216.7 & 87.7 \\
\hline Hydropsyche cockerelli & 70 & 22 & 73 & 165 & 55.0 & 28.6 \\
\hline Hydropsyche occidentalis & 171 & 64 & 111 & 349 & 115.3 & 53.6 \\
\hline Arctopsyche grandis & 7 & 4 & 15 & 26 & 8.7 & 5.7 \\
\hline GASTROPODA & 0 & 0 & 1 & 1 & 0.3 & 0.6 \\
\hline TOTAL ORGANISMS & 732 & 818 & 879 & 2429 & 809.7 & 73.9 \\
\hline
\end{tabular}



Table 24. Enumeration of macroinvertebrate taxa from Hess samples at the Missoula Site, January 23, 1997

\begin{tabular}{|c|c|c|c|c|c|c|}
\hline Taxon & Sample 1 & Sample 2 & Sample 3 & SUM & Mean & $\mathrm{SD}$ \\
\hline COLEOPTERA & 0 & 0 & 3 & 3 & 1.0 & 1.7 \\
\hline DIPTERA & 40 & 87 & 110 & 237 & 79.0 & 35.7 \\
\hline EPHEMEROPTERA & 35 & 36 & 10 & 90 & 30.0 & 9.5 \\
\hline PLECOPTERA & 47 & 55 & 30 & 132 & 44.0 & 12.8 \\
\hline Claassenia sabulosa & 10 & 0 & • & 21 & 7.0 & 2.6 \\
\hline Pteronarcys californica & 0 & 0 & 0 & 4 & 1.3 & 2.3 \\
\hline TRICHOPTERA & 10 & 32 & 22 & 68 & 22.7 & 9.0 \\
\hline Hydropsyche cockerelli & - & 12 & 4 & 18 & 6.0 & 5.3 \\
\hline Hydropsyche occidentalis & $\theta$ & 40 & 10 & 34 & 11.3 & 4.2 \\
\hline Arctopsyche grandis & - & 0 & 0 & 2 & 0.7 & 9.0 \\
\hline TOTAL ORGANISMS & 136 & 210 & 184 & 530 & 176.7 & 37.5 \\
\hline
\end{tabular}



Table 25. Enumeration of macroinvertebrate taxa from Hess samples at the Missoula site, August 12, 1997

\begin{tabular}{|c|c|c|c|c|c|c|}
\hline Taxon & Sample 1 & Sample 2 & Sample 3 & SUM & Mean & SD \\
\hline COLEOPTERA & 6 & 0 & 3 & 9 & 3.0 & 3.0 \\
\hline DIPTERA & 14 & 7 & 44 & 65 & 21.7 & 19.7 \\
\hline EPHEMEROPTERA & 80 & 157 & 98 & 294 & 98.0 & 9.0 \\
\hline PLECOPTERA & 22 & 16 & 16 & 54 & 18.0 & 3.5 \\
\hline Claassenia sabulosa & 6 & 10 & 7 & 26 & 8.0 & 1.5 \\
\hline Pteronarcys californica & 10 & 6 & 7 & 24 & 8.0 & 2.6 \\
\hline TRICHOPTERA & 268 & 276 & 233 & 777 & 259 & 22.9 \\
\hline Hydropsyche cockerelli & 201 & 157 & 164 & 522 & 174 & 23.6 \\
\hline Hydropsyche occidentalis & 25 & 25 & 10 & 68 & 20 & 8.7 \\
\hline Arctopsyche grandis & 7 & 31 & 21 & 59 & 19.7 & 12.1 \\
\hline TOTAL ORGANISMS & 399 & 406 & 394 & 1199 & 399.7 & 6.0 \\
\hline
\end{tabular}



percentage was only $9.7 \%$. The 1997 year-class of $H$. cockerelli may have been particularly strong relative to other caddisflies, but the differences in density may have also been due to a differences in the emergence times of the two previous year classes. The fact that the H. cockerelli were larger in August 1997 (mean of $11.3 \mathrm{~mm}$ total length, minimum of $10.0 \mathrm{~mm}$ ) than in July 1996 (mean 10.3 $\mathrm{mm}$, minimum $7.5 \mathrm{~mm}$ ) suggests that the 1996 year-class had emerged and reproduced earlier than the 1995 year-class and the new-generation larva were large enough to be sampled or were utilizing locations that we sampled.

In summary, the trends in seasonal insect abundance seemed to follow the natural pattern expected for temperate-region streams. The one exception to this was the sharp drop in total insect numbers from November 1996 to January 1997, although we suspect that local ice scour (not from above Milltown Dam) was responsible.

\section{Comparison with USGS Data}

There were three instances in 1996 and 1997 where the USGS sampled insects and sediments from the same site and at nearly the same time as samples collected for this study. In August 1996, the USGS sampled at the Alberton site about two weeks after sampling was done for this study, while in 1997, the USGS sampled both the Alberton and East Missoula sites about one week earlier than we did. The USGS analyzed 2-5 replicate samples for each insect species or sediment, while we had 2-3 replicate samples on all occasions for sediments and Claassenia and once for Arctopsyche. However, we only analyzed single samples for Hydropsyche cockerelli and in 2 of 3 instances for Arctopsyche, and these single samples preclude reliable comparisons between the studies.

The one instance where we analyzed three samples of Arctopsyche grandis was East Missoula in 1997, and the mean copper concentration in this study was $52.5 \mathrm{ug} / \mathrm{g}$, within $0.5 \%$ of the mean value of $54.6 \mathrm{ug} / \mathrm{g}$ calculated by the USGS (Table 26). Mean values for Claassenia were always somewhat higher for the USGS, ranging from 1\% higher at East Missoula in 1997 to 30\% higher at Alberton in 1996. The copper concentrations calculated by the USGS for sediments were always higher than those in this study. The mean USGS value was 25\% higher at Alberton in 1996 (136 vs $108.6 \mathrm{ug} / \mathrm{g}), 23 \%$ higher at Alberton in $1997(192 \mathrm{vs} 156 \mathrm{ug} / \mathrm{g})$, and $214 \%$ higher at East Missoula in 1997 (516 vs $241 \mathrm{ug} / \mathrm{g})$.

With the exception of the sediment samples at East Missoula in 1997, the copper concentrations calculated for this study are in good agreement with those generated by the USGS. Even differences up to $30 \%$ are probably not significant, given the standard deviation values associated with each mean. In addition, some of the differences may be due to variability in laboratory preparation and analysis. In this study, blind duplicates submitted to the laboratory varied by as much as $19 \%$. Finally, differences in the exact locations of sampling may also have contributed to the observed variations in copper levels. The sediments we sampled at Alberton in 1997 were from a spot several miles upstream from where the USGS sampled. Also, some of the insects that we sampled at 

Alberton in 1997 were from the same riffle sampled by the USGS, but some were from riffles up to a mile away.

Even with the differences between the studies, the USGS data are consistent with the finding in this study that copper concentrations in sediments increased with time at Alberton. Between August 1996 and August 1997, the USGS showed copper in sediment to increase 41\%, from $136 \mathrm{ug} / \mathrm{g}$ to 192 $\mathrm{ug} / \mathrm{g}$; likewise, in this study the sediment copper increased $44 \%$ over roughly the same time period. The USGS samples at Turah showed that this phenomenon was not restricted to the river below Milltown Dam. Between August 1996 and 1997, the sediment copper at Turah increased 78\%, from $356 \mathrm{ug} / \mathrm{g}$ to $635 \mathrm{ug} / \mathrm{g}$.

\section{Acknowledgments}

We wish to thank Russ Forba (USEPA) and Jim Scott (MDEQ) for acknowledging the need for this study and providing the funds to see it implemented. Dan McGuire of McGuire Consulting provided valuable assistance in helping us correctly identify the aquatic insects. Sam Luoma, Michelle Hornberger and Ellen Axtmann, all of the USGS, provided valuable suggestions to enable us to sample in accordance with their methods and techniques. Michelle Hornberger also provided useful comments on a draft of this report. 

Table 26. Comparison of mean ( \pm SD) copper concentrations (ug/g dry weight) in aquatic insects and fine-grained sediments in August 1996 and 1997 as measured by the USGS (Dodge et al. 1997, Dodge et al 1998, Homberger, pers. comm.) and in July 1996 and August 1997 from this study. Sample size is in parenthesis.

\begin{tabular}{|c|c|c|c|c|}
\hline \begin{tabular}{|l} 
Site/ \\
Collector
\end{tabular} & $\begin{array}{l}\text { Hydropsyche } \\
\text { cockerelli }\end{array}$ & $\begin{array}{l}\text { Arctopsyche } \\
\text { grandis }\end{array}$ & $\begin{array}{l}\text { Claassenia } \\
\text { sabulosa } \\
\end{array}$ & Sediment \\
\hline \multicolumn{5}{|c|}{1996} \\
\hline Turah (USGS) & $50.8 \pm 11.2(3)$ & $40.2 \pm 6.6(5)$ & $45.3 \pm 7.6(3)$ & $356 \pm 18(3)$ \\
\hline E. Missoula (This study) & $39.7(1)$ & $19.8(1)$ & $51.2 \pm 17.2(3)$ & $216.7 \pm 103(3)$ \\
\hline Missoula (This study) & $48.6(1)$ & $10.7 \pm 2.6(2)$ & $42.2 \pm 10.0(3)$ & $189.7 \pm 34(3)$ \\
\hline Allaterion (This stidy) & $28.5(1)$ & $20.1(1)$ & $4.3 .1,4.2,(3)$ & $108.6 .13 .(3)$ \\
\hline 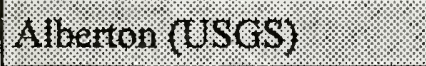 & $24.542 .8(3)$ & $13.1+2.7 .83$ & $(36.1,8.8 .3)$ & $(.56,6.67)$ \\
\hline \multicolumn{5}{|c|}{1997} \\
\hline Turah (USGS) & $109 \pm 7(3)$ & $92.9 \pm 25(5)$ & $64.2 \pm 18.6(3)$ & $635 \pm 31(3)$ \\
\hline 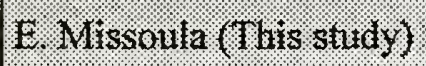 & $67.8(1)$ & $(52.5+4.0 .5 .8):$ & $43.8,5.3(3)$ & $241.0+42(3)$ \\
\hline 1. Missouta (USGS) & $89.2 .6 .4 .(3)$ & $(3.8 .6+20 .(3):$ & 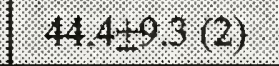 & $51.6262(3)$ \\
\hline Missoula (This study) & $46.3(1)$ & $24.7 \pm 1.0(2)$ & $42.0+14.8(3)$ & $335.3 \pm 51(3)$ \\
\hline Allertion (This stady) & $37.4(1)$ & $16.4(1)$ & $4.4 .1 .2 .8(2)$ & $156.0 \pm 3(3)$ \\
\hline Alberton (USCS) & 42.1 .4 .7 .7 .7$. & $28.6 .6 .9 .4)$ & $49.7 .7 .7(2):$ & $.192+1.7 .(3)$. \\
\hline
\end{tabular}





\section{References}

Boggs, S.J. 1994. Temporal and spatial variability of metal concentrations in fine-grained bed sediments and benthic insect larvae of the Clark Fork River, Montana. M.S. thesis, University of Montana. $115 \mathrm{pp}$.

Cain, D.J., S.N. Luoma, J.L. Carter, and S.V. Fend. 1992. Aquatic insects as bioindicators of trace element contamination in cobble-bottom rivers and streams. Can. J. Fish. Aquat. Sci. 49: 2141-2154.

Dodge, K.A., M.I. Hornberger, and E.V. Axtmann. 1997. Water-quality, bed-sediment, and biological data (October 1995 through September 1996) and statistical summaries of data for streams in the Upper Clark Fork Basin, Montana. U.S. Geological Survey, Open-file report 97-552. Helena, Montana. $91 \mathrm{pp}$.

Dodge, K.A., M.I. Hornberger, and E.V. Axtmann. 1998. Water-quality, bed-sediment, and biological data (October 1996 through September 1997) and statistical summaries of data for streams in the Upper Clark Fork Basin, Montana, Open-File Report 98-407. 102 pp.

Hornberger, M.L., J.H. Lambing, S.N. Luoma, and E.V. Axtmann. 1997. Spatial and temporal trends of trace metals in surface water, bed sediment, and biota of the Upper Clark Fork Basin, Montana, 1985-1995. U.S. Geological Survey, Open-file Report 97-669. Menlo Park California. 84 pp. plus appendices.

Hynes, H.B.N. 1970. The Ecology of Running Waters. Liverpool University Press. 555 pp.

Lambing, J.H. 1998. Estimated 1996-97 and Long-Term Average Annual Loads for Suspended Sediment and Selected Trace Metals in Streamflow of the Upper Clark Fork Basin from Warm Springs to Missoula, Montana. U.S. Geological Survey. Water-Resources Investigations Report 98-4137. Helena, Montana. 35 pp.

McGuire, D.L. 1997. Clark Fork River macroinvertebrate community biointegrity: 1995 Assessment. Prepared for the Montana Department of Environmental Quality. 61 pp. plus appendices.

SPSS. 1993. SPSS for Windows: Release 7.5. SPSS, Inc. Chicago, Il.

US Environmental Protection Agency. 1998. Draft Milltown Reservoir Sediments Operable Unit. Ecological Risk Assessment Addendum. Prepared by CH2MHill for the U.S. EPA Region 8. 



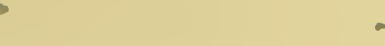


